\title{
ARTICLE
}

\section{THE BENEFIT CORPORATION: A QUESTIONABLE SOLUTION TO A NON-EXISTENT PROBLEM}

\section{JUSTIN BLOUNT ${ }^{*} \&$ KWABENA OFFEI-DANSO ${ }^{* *}$}

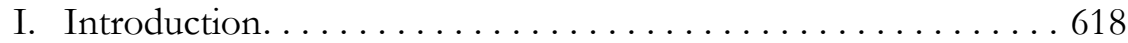

II. The MBCL. . . . . . . . . . . . . . . . . . . . . . . 621

A. The Purpose Behind the Creation of the MBCL. . . . . . . 622

1. A Brief History of Social Responsibility in Businesses . . 622

2. Present Demand for Socially-Conscious Organizations and the MBCL ....................... 625

B. The Structure of the Benefit Corporation . . . . . . . . . 627

1. Corporate Purpose . . . . . . . . . . . . . . . . . 628

2. Accountability........................6. 629

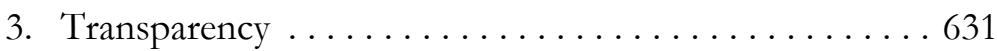

III. The Role of Business in Society and a Review of Theories That

Support the Benefit Corporation's Structure . . . . . . . . . . 632

A. Of Shareholder Primacy and Shareholder Wealth

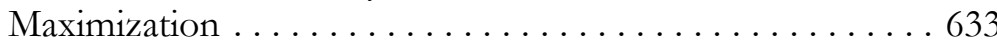

"Justin Blount is an Assistant Professor of Business Law in the Rusche College of Business at Stephen F. Austin University. B.B.A. in Finance, Southwestern Oklahoma State University; J.D., Baylor Law School; M.B.A., University of Texas at Austin.

${ }^{* *}$ Kwabena Offei-Danso is an in-house corporate attorney practicing in Waco, Texas. B.A. in Banking and Finance, Lincoln University of Pennsylvania; J.D., University of Houston Law Center. 
B. The Theoretical Underpinnings of the Benefit

Corporation Structure and Corporate Purpose . . . . . . . . 638

1. The Benefit Corporation As a Species of Stakeholder Theory. ..........................6640

2. The Benefit Corporation As a Species of Contractarian Theory. ........................641

IV. The Practical Implications of the Benefit Corporation's Structure. . . . . . . . . . . . . . . . . . . . . . . . 644

A. Shareholders' Rights..........................6 644

B Stakeholders' Rights . . . . . . . . . . . . . . . . . . . . . . . 648

C. The Organization's Ability to Meet Its Mission. . . . . . . 650

D. Officer and Director Accountability . ............. 653

E. Investors' Willingness to Provide Capital . . . . . . . 656

V. A Better Way: Ethical Managers Running Traditional Business Corporations . . . . . . . . . . . . . . . . . . . . . . . . 659

A. Business Corporations Can Maintain a Social Mission Under Current Corporate Law. . . . . . . . . . . . . . . . . . . 659

B. Available Corporate Law Mechanisms to Protect a Social Mission . . . . . . . . . . . . . . . . . . . . . . . . . . 663

1. Articles of Incorporation, Bylaws, or Shareholder Agreements Can State the Company's Social Mission. . 663

2. Founders Can Maintain Control Through Capital Structure . . . . . . . . . . . . . . . . . . . . 665

VI. Conclusion..............................669

\section{INTRODUCTION}

"No man can serve two masters: for either he will hate the one, and love the other; or else he will hold to the one, and despise the other. Ye cannot serve God and mammon."

This well-known Biblical admonition about conflicted loyalties exemplifies the purpose behind shareholder primacy-the legal principle that has long played an integral part in corporate governance in the United

1. Matthew 6:24 (King James). 
States. ${ }^{2}$ It is a fundamental premise of corporate law that when carrying out the corporation's affairs, officers and directors owe fiduciary duties of care and loyalty to the corporation and its shareholders, not to any other constituency. ${ }^{3}$ These exclusive duties give investors some measure of certainty that when they invest capital in an enterprise, their interests will be first and foremost in the minds of the managers. ${ }^{4}$ Any shareholderowned entity that deviates from this status quo risks derangement of shareholder and corporate interests.

The corporate entity has been instrumental in harnessing the profit motive to allow business enterprises to have a tremendous impact, both negative and positive, upon contemporary society. The proliferation of these entities also led to a tension in our society and our jurisprudence with respect to their purpose and impact on society. ${ }^{5}$ On the one hand, the corporate form's success led to a greater availability of products and services that increased our standard of living and quality of life. ${ }^{6}$ On the other hand, many believe the corporate form owes even more to society. ${ }^{7}$ Throughout American history there has been a continuous call for businesses to wield their power and influence in such a way as to not only create economic value for shareholders, but also to create value in an ethical manner that benefits society as a whole. ${ }^{8}$ Currently, many

2. See D. Gordon Smith, The Shareholder Primacy Norm, 23 J. CORP. L. 277, 296 (1998) (noting although courts did not develop the shareholder primacy norm until the 1830s, earlier business corporations and legal commentary "reflect a commitment to shareholder primacy" that pre-dates these court cases).

3. See Mills Acquisition Co. v. Macmillan, Inc., 559 A.2d 1261, 1280 (Del. 1989) (describing the fiduciary duty of corporate directors to shareholders); D. Gordon Smith, The Shareholder Primacy Norm, 23 J. CORP. L. 277, 278 (1998) ("Corporate director have a fiduciary duty to make decisions that are in the best interests of the shareholders.").

4. See Mills Acquisition Co., 559 A.2d at 1280 (exploring the purpose of fiduciary duties to shareholders).

5. See D. Gordon Smith, The Shareholder Primacy Norm, 23 J. CORP. L. 277, 323 (1998) (noting the tension between the shareholder primacy norm).

6. See B LAB, http://www.bcorporation.net/what-are-b-corps/why-b-corps-matter (last visited Apr. 3, 2013) (describing the success of the corporate form and how it can benefit society).

7. See Janet E. Kerr, Sustainability Meets Profitability: The Convenient Truth of How the Business Judgment Rule Protects a Board's Decision to Engage in Social Entrepreneurship, 29 CARDOZO L. REV. 623, 624 (2007) (pointing out corporations' increased interest in social entrepreneurship).

8. See E. Merrick Dodd, Jr., For Whom Are Corporate Managers Trustees?, 45 HARV. L. REv. 1145, 1153-54 (1932) ("If we may believe what some of our business leaders and students of business tell us, there is in fact a growing feeling not only that business has responsibilities to the community but that our corporate managers who control business should voluntarily and without waiting for legal compulsion manage it in such a way as to fulfill those responsibilities."); President Franklin D. Roosevelt, First Inaugural Address (Mar. 4, 1933) (transcript available in the National Archives), available at http://arcweb.archives.gov/arc/action/ExternalIdSearch?id=197333\&jScript=true ("The 
businesses respond to this call by integrating social responsibility into their operations. ${ }^{9}$ In modern business vernacular, such socially-responsible conduct is typically described using buzzwords such as "Corporate Social Responsibility," "Social Entrepreneurship," and "Creative Capitalism."10

A recent innovation on this front is the development of the "benefit corporation" by the non-profit organization "B Lab."11 The benefit corporation is essentially a hybrid entity, designed to have characteristics of both non-profit and for-profit entities and requires the managers and directors of these entities to seek a "material positive impact on society and the environment" while also generating a profit. ${ }^{12}$ B Lab advocates for two forms of the benefit corporation: the "Certified B Corporation" and the "Benefit Corporation (B Corp)."13 The Certified B Corporation is formed as a standard for-profit corporation under state law, but then undergoes certain procedures to obtain certification from B Lab. ${ }^{14}$ The Benefit Corporation is a legal status conferrable by states that recognize it as a legal business form under some variation of the Model Benefit Corporation Legislation (MBCL) B Lab promulgated. ${ }^{15}$ This Article

money changers have fled from their high seats in the temple of our civilization. We may now restore that temple to the ancient truths. The measure of the restoration lies in the extent to which we apply social values more noble than mere monetary profit.").

9. See Janet E. Kerr, The Creative Capitalism Spectrum: Evaluating Corporate Social Responsibility Through a Legal Lens, 81 TEMP. L. REV. 831, 832 (2008) (summarizing the various calls for social responsibility in business).

10. Id. at $832-33$.

11. See B LAB, http://www.bcorporation.net/what-are-b-corps/the-non-profit-behind-b-corps (last visited Apr. 3, 2013) ("B Lab is a 501(c)3 nonprofit that serves a global movement of entrepreneurs using the power of business to solve social and environmental problems.").

12. William H. Clark, Jr. et al., Model Benefit Corporation Legislation, BENEFIT CORP. INFO. CTR. (Dec. 21, 2012), at $\$ \int 102 \&$ 201, http://benefitcorp.net/storage/documents/Model_Benefit_ Corporation_Legislation.pdf.

13. See B LAB, http://www.bcorporation.net/what-are-b-corps/legislation (last visited Apr. 3, 2013) (explaining the difference between a Certified B Corporation and a Benefit Corporation).

14. B LAB, http://www.bcorporation.net/what-are-b-corps/legislation (last visited Apr. 3, 2013). These procedures include taking a "B Impact Assessment" test, completing an assessment review, submitting supporting documentation supporting the answers to the assessment, adopting amendments to the organization's corporate governing documents that incorporate consideration of stakeholder interests, and paying review certification fees to B Lab. See B LAB, http://www.bcorporation.net/become-a-b-corp/how-to-become-a-b-corp (last visited Apr. 3, 2013) (defining procedures to become a Certified B Corporation); B LAB, http://www.bcorporation.net/ become-a-b-corp/how-to-become-a-b-corp/performance-requirements (last visited Apr. 3, 2013) (setting forth the performance requirements).

15. While not codified, this model legislation is influential in the movement toward benefit corporation business forms. William H. Clark, Jr., an attorney from Drinker, Biddle \& Reath, LLP in Philadelphia, drafted the MBCL. It continues to develop as legislators pass their own versions of the 
focuses only on the second type of benefit corporation, and all references to benefit corporation in this Article refer only to these entities.

At the time of this writing, twelve states have enacted some form of a benefit corporation statute; fourteen states and Washington, D.C. have introduced legislation to permit these entities. ${ }^{16}$ This Article analyzes the corporate governance structure created by the MBCL and discusses the inherent conflicts and problems it has created. Part II discusses the reasons behind the development of benefit corporations and how the MBCL attempts to create a new entity that better accommodates both a profit motive and a social mission. Part III discusses the ongoing debate with respect to the corporation's purpose and its relationship to society and analyzes issues the creation of the benefit corporation produces relating to corporate governance theory. Part IV analyzes the practical problems created by the benefit corporation's corporate structure. Part V discusses how to meet the needs of socially minded corporations under existing corporate law. Finally, Part VI offers concluding remarks.

\section{THE MBCL}

The MBCL is a response to a perceived need for a business entity form that accommodates the needs of consumers, investors, and entrepreneurs who care as much about social issues as product costs and profits. ${ }^{17}$ Although very few cases have addressed the conflict between a

MBCL in their home states with various modifications. William H. Clark, Jr. et al., Model Benefit Corporation Legislation, BENEFIT CORP. INFO. CTR., http://benefitcorp.net/for-attorneys/modellegislation (last visited Apr. 3, 2013) ("[The MBCL] reflects the expressed needs of business leaders and investors interested in using the power of business to solve social and environmental problems, and has been conformed to local corporate codes by local corporate attorneys."').

16. See State by State Legislative Status, BENEFIT CORP INFO. CTR, http://www.benefitcorp.net/ state-by-state-legislative-status (last visited Apr. 3, 2013). The states that have adopted some form of benefit corporation legislation are California, Hawaii, Illinois, Maryland, Massachusetts, Louisiana, New Jersey, New York, Pennsylvania, South Carolina, Vermont, and Virginia. Id. The states that have introduced legislation are Alabama, Arizona, Arkansas, Connecticut, Delaware, Florida, Iowa, Montana, Nevada, North Carolina, Oregon, Rhode Island, Texas, West Virginia, and Washington DC. Id. While these states laws substantially reflect the Model Benefit Corporation Legislation, they are not uniform. Because this Article focuses conceptually on the overall changes to corporate governance advocated by the Model Benefit Corporation Legislation, it will not focus on the differences among the versions of the legislation adopted in these states.

17. See William H. Clark, JR., ET al., The Need and Rationale for the Benefit CORPoration: Why It Is THE LEgal Form that BeST AdDRESSES THE NeEdS OF SOCIAL ENTREPRENEurs, InVestors, AND, Ultimately, the Public 2-5 (2012) [hereinafter Benefit CORP. WHITE PAPER], available at http://www.benefitcorp.net/for-attorneys/benefit-corp-whitepaper (discussing increased societal concern over socially responsible corporate behavior). 
corporation's duty to maximize shareholder profits and its pursuit of social or charitable goals, according to the drafters of the MBCL, many social entrepreneurs continue to believe the law forbids them from furthering social goals when those goals do not result in increased profits. ${ }^{18}$ In light of this and in the face of a perceived growth in the trend towards social entrepreneurship, ${ }^{19}$ corporate social responsibility (CSR), and sociallyresponsible investment (SRI), the MCBL intends to create a new legal form to accommodate these needs. ${ }^{20}$

\section{A. The Purpose Behind the Creation of the MBCL}

\section{A Brief History of Social Responsibility in Businesses}

The concept of SRI is not a modern phenomenon. ${ }^{21}$ In fact, several religious texts outline ethically-sound investment techniques, and their adherents have practiced SRI for centuries. ${ }^{22}$ For example, both Jewish

18. See id. at 7-8 (examining case history that emphasized financial gain as the primary goal businesses have for shareholders).

19. Although the White Paper refers to "social entrepreneurship" or "social enterprise" several times, the paper, along with the MBCL, fails to define these terms. Moreover, different scholars attach diverse interpretations to these terms. See Peter A. Dacin, M. Tina Dacin \& Margaret Matear, Social Entrepreneurship: Why We Don't Need a New Theory and How We Move Forward from Here, 24 ACAD. MGMT. REV. PersP. 37, 39-41 (2010) (listing the various definitions of social entrepreneurship). For example, one scholar defines social entrepreneurship as "the creation and undertaking of a venture intended to promote a specific social purpose or cause in a context of mobilization." Patrick J. Murphy \& Susan M. Coombes, A Model of Social Entrepreneurial Discovery, 87 J. Bus. ETHICs 325, 326 (2009). Another "focuses on social entrepreneurship that creates innovative solutions to immediate social problems and [mobilizing] the ideas, capacities, resources, and social arrangements required for long-term, sustainable, social transformations." Sarah H. Alvord, L. David Brown \& Christine W. Letts, Social Entrepreneurship and Societal Transformation: An Exploratory Study, 40 J. APPLIED BEHAV. SCI. 260, 262 (2003). Still another defines social enterprises as "[c]ompanies ... that measure value creation as a combination of profits and impact on people, the environment, or both ...." Steven J. Haymore, Public(y Oriented) Companies: B Corporations and the Delaware Stakeholder Provision Dilemma, 64 VAND. L. REV. 1311, 1313 (2011); accord Thomas Kelley, Law and Choice of Entity on the Social Enterprise Frontier, 84 TUL. L. REV. 337, 339 (2009) (explaining social entrepreneurs do not necessarily operate as nonprofit officers, but more as business managers with multiple objectives). For the purpose of this Article, these terms represent the third meaning-i.e., relating to "[c]ompanies ... that measure value creation as a combination of profits and impact on people, the environment, or both." Steven J. Haymore, Public(y Oriented) Companies: B Corporations and the Delaware Stakeholder Provision Dilemma, 64 VAND. L. REV. 1311, 1313 (2011).

20. BENEFIT CORP. WHITE PAPER, at 3-4 \& app. C, at 7.

21. See Steve Schueth, Socially Responsible Investing in the United States, 43 J. Bus. ETHICs 189, 189 90 (2003) (showing the concept of socially-responsible investing originated in biblical times and continued to evolve through the modern era).

22. See John Wesley, The Use of Money, Sermon 50 (1872), available at http://www.umc mission.org/Find-Resources/Global-Worship-and-Spiritual-Growth/John-Wesley- 
and Islamic religious texts outline ways to invest ethically and specifically address usury and interest. ${ }^{23}$ Quakers and Methodists, inspired by John Wesley, have long believed in only investing in socially conscious organizations and historically refused to invest in businesses associated with war and slavery. ${ }^{24} \mathrm{~A}$ small minority of businesses and investment companies catered to these socially-conscious investors. ${ }^{25}$ The modern trend, however, stems from a secular movement towards social consciousness. ${ }^{26}$

The political climate of the 1960s and 1970s, coupled with the technological revolution that made information more easily accessible,

Sermons/Sermon-50-The-Use-of-Money ("We ought to gain all we can gain but this it is certain we ought not to do; we ought not to gain money at the expense of life, nor at the expense of our health."); see also Deuteronomy 14:28-29 (King James) ("[T]hou shalt bring forth all the tithe of thine increase the same year, and shalt lay it up within thy gates ... and the stranger, and the fatherless, and the widow, which are within thy gates, shall come, and shall eat and be satisfied ....") (emphasis added); Genesis 32:8-9 (King James) (urging diversification of assets); THE QUR'AN 2:275 (Tarif Khalidi trans. 2008) ("God has made commerce licit and usury illicit.").

23. See Steven H. Resnicoff, Jewish Law and Socially Responsible Corporate Conduct, 11 FORDHAM J. CORP. \& FIN. L. 681, 694 (2006) ("Jewish law comprehensively controls corporate conduct from within by imposing pervasive rules on the actions that corporate employees, managers, directors, and shareholders may and must take. These rules prevent a panoply of socially irresponsible actions and require many affirmatively responsible deeds."); see also CHIARA SEGRADO, CASE STUDY: ISLAMIC MiCROFINANCE AND SOCIALlY RESPONSIBLE INVESTMENTS 8-11 (2005), available at http://www.gdrc.org/icm/islamic-microfinance.pdf (identifying the Islamic principles behind banking and financing contracts); Deuteronomy 14:22-26 (King James) (providing rules for how to expend money and requiring the payment of tithes); Exodus 22:25 (King James) (proscribing interest on loans); THE QUR'AN 2:275 (Tarif Khalidi trans. 2008) (prohibiting usury, interest, and gambling).

24. See Benjamin J. Richardson, Putting Ethics into Environmental Law: Fiduciary Duties for Ethical Investment, 46 OSGOODE HALL L.J. 243, 245-46 (2008) (noting the Quakers began ethical investing in the 1770s with a focus on slavery, but their efforts have since shifted to firms that engage in vices such as dealing in tobacco or disregarding human rights); see also DIMITRIS MICHARIKOPOULOS \& Felina Danalis, SOCIALly RESPONSIBLE INVESTMENT-CURRENT STATE OF SRI PRACTICES AND Regulation in Select EU COUNTRIES: Cyprus, GreECE AND THE UNited Kingdom 5 (2010), available at http://www.mytilineos.gr/ uploads/ csresponsibility/ ISI_SRI_Report_GR _CY_UK_2010.pdf (explaining the investment philosophies of Quakers and Methodists).

25. See Dimitris Micharikopoulos \& Felina DANAlis, SOCIAlly Responsible INVESTMENT-CURRENT STATE OF SRI PRACTICES AND REgUlation IN SELECT EU COUNTRIES: CYPRUS, GREECE AND THE UNITED KINGDOM 5 (2010), available at http://www.mytilineos.gr/uploads/csresponsibility/ISI_SRI_Report_GR_CY_UK_2010.pdf (noting the sudden growth of the socially-conscious business industry, starting in the recent past and also noting that certain businesses catered to socially conscious investors).

26. See id. (commenting the modern movement "expressed itself largely in the political and social upheavals of the $1950 \mathrm{~s}-1970 \mathrm{~s}$ " as opposed to "focusing on ethical considerations tied to religious values"). 
spurred further growth in SRI. ${ }^{27}$ After the success of the civil rights era, America's collective focus shifted to other social issues including apartheid in South Africa, the Cold War, the rights of women, healthy working conditions, slave and child labor in developing countries, and nuclear proliferation. $^{28}$ Due to the accessibility of information, millions of constituents became aware of these issues and began incorporating social issues into their consumption and investment decisions. ${ }^{29}$ Socially conscious consumers realized they could affect positive change by patronizing companies whose social missions aligned with theirs, and their consumption focus shifted from purely price and quality to also considering the effects that products and their manufacturers had on society. ${ }^{30}$ Investors followed suit, seeking to benefit from companies that obtained both financial and social results as opposed to only profits. ${ }^{31}$

The 1990s witnessed a rise in socially conscious businesses motivated by the desire to be different and to appeal to a different constituentemployees and potential employees. ${ }^{32}$ Entrepreneurs sought to hire the best talent and discovered the most efficient strategy for achieving a competitive advantage was through differentiation. ${ }^{33}$ Due to competition, image became a large element of employee recruiting. ${ }^{34}$ Employees

27. Susan N. Gary, Is It Prudent to Be Responsible? The Legal Rules of Charities That Engage in Socially Responsible Investing and Mission Investing, 6 NW. J. L. \& SOC. POL’Y 106, 110 (2011).

28. See id. (describing the socially responsible investing trend); David Monsma \& John Buckley, Non-Financial Corporate Performance: The Material Edges of Social and Environmental Disclosure, 11 U. BALT. J. ENVTL. L. 151, 190 (2004) (describing how companies and consumers contributed to the end of South Africa's apartheid policy).

29. See Steve Schueth, Socially Responsible Investing in the United States, 43 J. Bus. ETHICS 189, 190 (2003) (identifying motivations for investors "attracted to socially responsible investing").

30. See Janet E. Kerr, The Creative Capitalism Spectrum: Evaluating Corporate Social Responsibility Through a Legal Lens, 81 TEMP. L. REV. 831, 832 (2008) (noting that corporate social responsibility is driven by consumer demand).

31. Id.

32. Janet E. Kerr, Sustainability Meets Profitability: The Convenient Truth of How the Business Judgment Rule Protects a Board's Decision to Engage in Social Entrepreneurship, 29 CARDOZO L. REV. 623, 641-42 (2007); see also Alexander Schieffer \& Ronnie Lessem, Beyond Social and Private Enterprise: Towards the Integrated Enterprise, 15 TRANSITION STUD. REV. 713, 714 (2009) (commenting that businesses are becoming socially responsible to foster self-preservation); Briana Cummings, Note, Benefit Corporations: How to Enforce a Mandate to Promote the Public Interest, 112 COLUM. L. REV. 578, 582 (2012) (arguing potential employees are also pressuring corporations to be socially responsible).

33. Janet E. Kerr, Sustainability Meets Profitability: The Convenient Truth of How the Business Judgment Rule Protects a Board's Decision to Engage in Social Entrepreneurship, 29 CARDOZO L. REV. 623, 641-42 (2007).

34. See William H. Gates, Chairman, Microsoft Corp., Remarks at the World Economic Forum 2008: A New Approach to Capitalism in the 21st Century (Jan. 24, 2008), available at http://www.microsoft.com/en-us/news/exec/billg/speeches/2008/01-24WEFDavos.aspx (arguing 
gravitated towards companies they believed were kind to society and the environment, and took with them their intellectual resources. ${ }^{35}$ Businesses adjusted their focus accordingly. ${ }^{36}$

\section{Present Demand for Socially-Conscious Organizations and the}

\section{MBCL}

The drafters of the MBCL believe SRI and social entrepreneurship have now reached an inflection point such that investors, consumers, and entrepreneurs need a new business form to accommodate their needs. ${ }^{37}$ They point out that a significant number of consumers state they prefer products made in a socially and environmentally responsible manner. ${ }^{38}$ However, in an effort to attract these socially and environmentally conscious consumers, the drafters claim companies and marketers have resorted to advertising gimmicks. ${ }^{39}$ Terms like "green," "sustainable," "organic," "fair-trade," and "socially responsible" attract such consumers. ${ }^{40}$ As with all marketing, without checks and verification mechanisms, fraud and misrepresentation can become rampant. ${ }^{41}$ Some legal observers perceive the socially-driven industry as moving in that direction and assert that "[e]xisting legal doctrines and entity structures cannot adequately meet the needs of what are essentially hybrid

that to the extent that profitability is reduced by social consciousness, the value of recognition which attracts motivated talent and enhances the company's reputation makes up for the decrease in profits).

35. See id. (contending that there are numerous actions employers can take to incentivize employees to work for them).

36. Janet E. Kerr, Sustainability Meets Profitability: The Convenient Truth of How the Business Judgment Rule Protects a Board's Decision to Engage in Social Entrepreneurship, 29 CARDOZO L. REV. 623, 639-40 (2007).

37. See William H. Clark, Jr., et Al., The Need and Rationale for the Benefit CORPORATION: WHY IT IS THE LEGAL FORM THAT BEST ADDRESSES THE NEEDS OF SOCIAL ENTREPRENEURS, INVESTORS, AND, ULTIMATELY, THE PUBLIC 2-5 (2012), available at http://www.benefitcorp.net/for-attorneys/benefit-corp-white-paper (indicating changes in how investors, consumers, and entrepreneurs do business).

38. See id. at 2 (citing Cone Communications, Cone Cause Evolution \& Environment Survey, Cone Research Report, at 8 (2007), available at http://www.coneinc.com/files/2007/ConeSurvey Report.pdf) (noting that research indicates $86 \%$ of consumers state they would switch from their current brand to a more socially responsible brand, if price and quality were comparable).

39. Id. at $2-3$.

40. Id. at 2

41. See Janet E. Kerr, The Creative Capitalism Spectrum: Evaluating Corporate Social Responsibility Through a Legal Lens, 81 TEMP. L. REV. 831, 843-48 (2008) (pointing to allegations of greenwashing by Nike as evidence of the potential for misrepresentation in marketing in the social entrepreneurship industry). 
organizations that fulfill both for-profit and nonprofit functions." 42 Thus, they argue a uniform standard would allow companies to verify such marketing claims. ${ }^{43}$

Furthermore, proponents of the MBCL argue the proliferation of socially-responsible investors created the need for an organized framework for socially-conscious distribution or investment of capital. ${ }^{44}$ The size of the SRI market is already quite large and continues growing. ${ }^{45}$ The drafters of the MBCL assert there are few comprehensive tools to allow SRI investors to evaluate companies that purport to be socially and environmentally conscious, and to distinguish truly socially responsible companies from those who are socially conscious in name only. ${ }^{46}$

The drafters of the MBCL also emphasize that a large group of socially minded entrepreneurs wish to further social missions, but do not want to operate through non-profit entities. ${ }^{47}$ Socially driven entrepreneurs go against the traditional single-dimensional perception of managers by acknowledging that profit is an objective of the firm, but not the primary goal. ${ }^{48}$ Proponents of the MBCL argue such entrepreneurs would benefit from a corporate form that specifically allows the pursuit of a social mission as a valid purpose of the organization. ${ }^{49}$

Although some social entrepreneurs successfully accomplished their

42. Christopher Lacovara, Note, Strange Creatures: A Hybrid Approach to Fiduciary Duty in Benefit Corporations, 2011 COLUM. BuS. L. REV. 815, 818-19.

43. See BENEFIT CORP. White PAPER, at 3 (noting how entrepreneurs have recognized problems with government tax codes).

44. See id. at 3-4 (identifying that entrepreneurs have recognized problems with government tax codes); see also Ryan J. Gaffney, Hype and Hostility for Hybrid Companies: A Fourth Sector Case Study, 5 J. BUS. ENTREPRENEURSHIP \& L. 329, 330 (2012) (describing the different business forms created by state legislatures in response to entrepreneurs' business goals).

45. See Benefit Corp. White PAPer, at 4 (citing J.P. Morgan Global Research, Impact Investments: An Emerging Asset Class (Nov. 29, 2010), available at

http://www.jpmorgan.com/cm/BlobServer/impact_investments_nov2010.pdf?blobkey=id\&blobw here $=1158611333228 \&$ blobheader $=$ application $\% 2$ Fpdf\&blobcol $=$ urldata\&blobtable $=$ MungoBlobs (discussing the size of the SSI market); see Alicia E. Plerhoples, Can an Old Dog Learn New Tricks? Applying Traditional Corporate Law Principles to New Social Enterprise Legislation, 13 TRANSACTIONS TENN. J. BUS. L. 221, 233-35 (2012) (forecasting the growth of the socially-responsible business market); see also W. Edward Afield, Getting Faith Out of the Gutters: Resolving the Debate over Political Campaign Participation by Religious Organizations Through Fiscal Subsidiarity, 12 NEV. L.J. 83, 109 (2011) (explaining the growth of socially-responsible investment funds).

46. BENEFIT CORP. WHITE PAPER, at 4-5.

47. Id. at 7 .

48. Alexander Schieffer \& Ronnie Lessem, Beyond Social and Private Enterprise: Towards the Integrated Enterprise, 15 TRANSITION STUD. REV. 713, 715 (2009).

49. See BENEFIT CORP. White PAPER, at 5 (describing the growing market for companies who seek profits yet have socially-minded goals). 
social objectives while operating under the traditional corporate code, ${ }^{50}$ others have voiced their fear of navigating the murky waters of corporate social responsibility in light of the perceived nature of corporate law-i.e., shareholder wealth maximization - and the possibility of director liability for socially responsible, but profit-minimizing, decisions. ${ }^{51}$ The drafters of the MBCL described the benefit corporation as a solution to this perceived problem. ${ }^{52}$

In sum, the drafters of the MBCL cite the main purposes of the benefit corporation as the following: (1) to offer consumers and financiers protection against misrepresentation and to encourage transparency by mandating disclosure of information to ensure that socially-driven companies are bound to their respective social purposes; (2) to clearly identify firms with socially conscious ambitions and to align the interests of socially-conscious financiers, entrepreneurs, and consumers; and (3) to create a legal framework which would be instrumental in achieving social goals that traditional corporations may be hindered from accomplishing. ${ }^{53}$

\section{B. The Structure of the Benefit Corporation}

The MBCL provides that the respective state's corporate code governs the benefit corporation, except where the MBCL specifically states otherwise. ${ }^{54}$ Benefit corporation formation is the same as business corporation formation, but its articles of incorporation must specifically state that the organization will be a benefit corporation. ${ }^{55}$ An existing corporation may choose to become a benefit corporation if a two-thirds

50. See J. Gregory Dees \& Beth Battle Anderson, For-Profit Social Ventures, 2 SOC. ENTREPRENEURSHIP 17-19 (2003) (providing examples of corporations that achieved social goals while pursuing the primary goal of profitmaking).

51. See, e.g., Christopher Lacovara, Note, Strange Creatures: A Hybrid Approach to Fiduciary Duty in Benefit Corporations, 2011 COLUM. BUS. L. REV. 815, 818-19 ("Existing legal doctrines and entity structures cannot adequately meet the needs of what are essentially hybrid organizations that fulfill both for-profit and [non-profit] functions.").

52. See BenEFIT CORP. White PAPER, at 4-5 (arguing the benefit corporation is the best method for corporations to achieve social goals); Ryan J. Gaffney, Hype and Hostility for Hybrid Companies: A Fourth Sector Case Study, 5 J. Bus. ENTREPRENEURSHIP \& L. 329, 331 (2012) (describing how different business forms created by state legislatures should help social entrepreneurs and businesses achieve their goals).

53. See generally BENEFIT CORP. WHITE PAPER (summarizing the primary purposes of the benefit corporation).

54. William H. Clark, Jr. et al., Model Benefit Corporation Legislation, BENEFIT CORP. INFO. CTR.

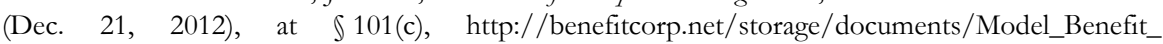
Corporation_Legislation.pdf.

55. Id. at $\$ 103$. 
supermajority of the holders of each class of its shares vote to amend its articles to state that it is a benefit corporation. ${ }^{56}$ Furthermore, a business entity that undergoes a fundamental transaction, including a merger, consolidation, division, or an exchange that would result in the creation of a benefit corporation, must receive approval from a two-thirds supermajority of the holders of each class of its shares. ${ }^{57}$ The benefit corporation deviates significantly from the traditional corporate form by allowing the organization's corporate purpose to accommodate a social mission and focusing on accountability and transparency. ${ }^{58}$

\section{Corporate Purpose}

According to the MBCL, the corporate purpose of a benefit corporation must be the creation of a "general public benefit." 59 The MBCL defines a general public benefit as "[a] material positive impact on society and the environment, taken as a whole, assessed against a third-party standard, from the business and operations of a benefit corporation."60 In addition, benefit corporations may specify one or more "specific public benefits" they wish to pursue and create. ${ }^{61}$ The MBCL enumerates seven possible, non-exclusive, specific public benefits a benefit corporation can provide in its articles:

(1) providing low-income or underserved individuals or communities with beneficial products or services;

(2) promoting economic opportunity for individuals or communities beyond the creation of jobs in the ordinary course of business;

(3) protecting or restoring the environment;

(4) improving human health;

(5) promoting the arts, sciences, or advancement of knowledge;

(6) increasing the flow of capital to entities with a purpose to benefit society or the environment; and

(7) conferring any other particular benefit on society or the environment. ${ }^{62}$

56. Id. at $₫ 104(\mathrm{a})$.

57. Id. at $\$ 104(\mathrm{~b})$

58. See BENEFIT CORP. WHITE PAPER, at 16 (noting the structural differences in the benefit corporation and the traditional corporation).

59. William H. Clark, Jr. et al., Model Benefit Corporation Legislation, BENEFIT CORP. INFO. CTR. (Dec. 21, 2012), at \201(a), http://benefitcorp.net/storage/documents/Model_Benefit_ Corporation_Legislation.pdf.

60. Id. \102.

61. Id.

62. Id. 
To protect benefit corporations from potential suits for performing their stated social goals, the statute expressly states, "The creation of general public benefit and specific public benefit ... is in the best interests of the benefit corporation." 63

\section{Accountability}

The MBCL creates additional factors, besides the interests of shareholders, which the benefit corporation's board of directors, committees, and individual directors are required to consider in the discharge of their obligations. ${ }^{64}$ The MBCL delineates both mandatory and permissive considerations for management ${ }^{65}$ and grants each officer discretion to act regarding a specific matter when it "reasonably appears to the officer that the matter may have a material effect on the creation by the benefit corporation of a general public benefit or a specific public benefit identified in the articles of incorporation of the benefit corporation." 66

With so many constituents and interests to consider, potential liability could be limitless. Thus, the drafters of the MBCL limits director and officer liability in several ways. ${ }^{67}$ First, the MBCL generally shields directors from liability for considering interests listed in the statute and the entity's articles in carrying out their duties, and expressly removes personal

63. Id. \201(c).

64. Id. \$301(a).

65. Id. The benefit corporation must consider the following:

(i) the shareholders of the benefit corporation; (ii) the employees and work force of the benefit corporation, its subsidiaries, and its suppliers; (iii) the interests of customers as beneficiaries of the general public benefit or specific public benefit purposes of the benefit corporation; (iv) community and societal factors, including those of each community in which offices or facilities of the benefit corporation, its subsidiaries, or its suppliers are located; (v) the local and global environment; (vi) the short-term and long-term interests of the benefit corporation, including benefits that may accrue to the benefit corporation from its long-term plans and the possibility that these interests may be best served by the continued independence of the benefit corporation; and (vii) the ability of the benefit corporation to accomplish its general public benefit purpose and any specific public benefit purpose.

It may also consider the following: [i) the interests referred to in [cite constituencies provision of the business corporation law if it refers to constituencies not listed above]; and (ii)] other pertinent factors or the interests of any other group that they deem appropriate . . . Id. \301(a)(1)-(2) (alterations in original).

66. Id. $\$ 303(\mathrm{a})$.

67. See generally id. $₫ 301-03$ (detailing the protection provided to corporations that decide to pursue social goals). 
liability for monetary damages. ${ }^{68}$ The elimination of personal monetary liability extends to all actions and inactions by directors or officers, provided their actions comply with the general corporate code's law on officer and director duties. ${ }^{69}$ Second, benefit directors have the additional protection of escaping personal liability for acts and omissions performed in the course of their duties in the absence of willful misconduct, illegal activities, or self-dealing. ${ }^{70}$ Third, although the MBCL seeks to create broad social good, it limits standing to sue a benefit corporation to its shareholders and certain other limited parties, but not to other stakeholders generally. ${ }^{71}$

Fourth and most remarkably, the MBCL abrogates all traditional causes of action related to improper administration of the corporation and replaces them with the "benefit enforcement proceeding." enforcement proceedings are the sole remedy not only for actions regarding the failure of the benefit corporation to "pursue or create general public benefit or a specific public benefit set forth in its articles," but also extends to actions alleging "violation of an obligation, duty, or standard of conduct under [the MBCL]," including actions for breach of the traditional fiduciary duties. ${ }^{73}$ Standing to bring a benefit enforcement action is limited to the benefit corporation. ${ }^{74}$ However, shareholders, directors, owners of $5 \%$ or more of a parent of the benefit corporation, or any additional person specifically set forth in the benefit corporation's

68. Id. $\iint 301$ (c) \& 303(c).

69. Id. SS 301-03; see also William H. Clark, Jr. \& Elizabeth K. Babson, How Benefit Corporations Are Redefining the Purpose of Business Corporations, 38 WM. MitChell L. REV. 817, 848-49 (2012) (noting the abrogation of personal liability for monetary damages is intended to remove concerns regarding the quantification of damages and to focus courts on the beneficial purpose of the benefit corporation).

70. William H. Clark, Jr. et al., Model Benefit Corporation Legislation, BENEFIT CORP. INFO. CTR. (Dec. 21, 2012), at \302(e), http://benefitcorp.net/storage/documents/Model_Benefit_ Corporation_Legislation.pdf.

71. See id. $\$ 301$ (d) (detailing that being a beneficiary does not confer standing); see also id. $\int 301(\mathrm{~d}) \mathrm{cmt}$. (stating unless otherwise specified in the benefit corporation's articles, the MBCL "negates any enforceable duty of directors to non-shareholder constituents"); Dana Brakman Reiser, Benefit Corporations-A Sustainable Form of Organization?, 46 WAKE FOREST L. REV. 591, 599 (2011) (explaining how shareholders invested in socially-minded corporations protect themselves against lawsuits).

72. William H. Clark, Jr. et al., Model Benefit Corporation Legislation, BENEFIT CORP. INFO. CTR, (Dec. 21, 2012), at $\ 305$, http://benefitcorp.net/storage/documents/Model_Benefit_Corporation_ Legislation.pdf; see also id. $\$ 102 \mathrm{cmt}$. (describing that the definition of the benefit enforcement proceeding in effect excludes all actions against a benefit corporation and its directors and officers).

73. Id. $\$ 305(\mathrm{a})$.

74. Id. \305(b). 
bylaws or articles of incorporation may bring a derivative benefit enforcement suit. ${ }^{75}$ Thus, as with traditional corporations, benefit corporation's beneficiaries have no cause of action against a benefit corporation that does not perform its stated social good. ${ }^{76}$

\section{Transparency}

The MBCL requires a benefit corporation's board of directors to appoint an "independent benefit director" who has no "material relationship with the benefit corporation or a subsidiary of the corporation." 77 This individual holds the duty to prepare and deliver to shareholders annual compliance statements that state the opinion of the benefit director on the following:

(1) Whether the benefit corporation acted in accordance with its general public benefit purpose and any specific public benefit purpose in all material respects during the period covered by the report.

(2) Whether the directors and officers complied with sections 301(a) [Directors' Consideration of Stakeholder Interests] and 303(a) [Officers' Consideration of Stakeholder Interests], respectively.

75. Id.

76. See id. $\$ 301$ (d) (declining to confer standing to persons with mere beneficiary status); see also id. $\ 301$ (d) cmt. (stating unless otherwise specified in the benefit corporation's articles, the MBCL "negates any enforceable duty of directors to non-shareholder constituents"); Dana Brakman Reiser, Benefit Corporations-A Sustainable Form of Organization?, 46 WAKE FOREST L. REV. 591, 599 (2011) (discussing litigation protections available to socially minded shareholder investors).

77. William H. Clark, Jr. et al., Model Benefit Corporation Legislation, BENEFIT CORP. INFO. CTR. (Dec. 21, 2012), at $\$ 102$, http://benefitcorp.net/storage/documents/Model_Benefit_Corporation_ Legislation.pdf. The MBCL establishes a conclusive presumption of a material relationship if:

(1) The individual is, or has been within the last three years, an employee other than a benefit officer of the benefit corporation or a subsidiary.

(2) An immediate family member of the individual is, or has been within the last three years, an executive officer other than a benefit officer of the benefit corporation or a subsidiary.

(3) There is beneficial or record ownership of $5 \%$ or more of the outstanding shares of the benefit corporation ... by:

(i) the individual; or

(ii) an entity:

(A) of which the individual is a director, an officer, or a manager; or

(B) in which the individual owns beneficially or of record $5 \%$ or more of the outstanding equity interests ....

Id. 
(3) If, in the opinion of the benefit director, the benefit corporation or its directors or officers failed to comply with paragraph (2), a description of the ways in which the benefit corporation or its directors or officers failed to comply. ${ }^{78}$

To ensure transparency, the MBCL also requires the benefit director prepare annual benefit reports that must include an annual compliance statement-a narrative description of how "the benefit corporation pursued general public benefit," and "[a]n assessment of the overall social and environmental performance of the benefit corporation against a thirdparty standard."79 Third-party certification is not a requirement for the annual benefit report. ${ }^{80}$ The benefit director must file the report with the secretary of state in the benefit corporation's state of incorporation and make the report available to the public by displaying it on the company's website. ${ }^{81}$ The benefit corporation may also appoint a benefit officer (who may be the benefit director) who bears the duty to prepare the annual benefit reports. ${ }^{82}$

\section{The Role of Business In SOCIETY AND A REVIEW OF THEORIES THAT SUPPORT THE BENEFIT CORPORATION’s STRUCTURE}

The drafters of the MBCL state, "It is against the paradigm of shareholder primacy that benefit corporation statutes have been drafted." 83 To analyze this claim, one must first understand the doctrine of shareholder primacy, as well as the norm of shareholder wealth maximization typically associated with it. ${ }^{84}$ To understand why the structure of the benefit corporation as proposed in the MBCL fails to

78. Id. $\int 302(\mathrm{c})$.

79. Id. $₫ 401(\mathrm{a})$.

80. See William H. Clark, JR., ET Al., The Need and Rationale for the Benefit Corporation: Why It Is the Legal Form that Best AdDresses the NeEds of Social Entrepreneurs, InVestors, And, Ultimately, the Public 25 (2012), available at http://www.benefitcorp.net/for-attorneys/benefit-corp-white-paper (indicating it is not required that third parties certify or audit a benefit corporation's benefit report).

81. William H. Clark, Jr. et al., Model Benefit Corporation Legislation, BENEFIT CORP. INFO. CTR. (Dec. 21, 2012), at $\ 402$, http://benefitcorp.net/storage/documents/Model_Benefit_Corporation_ Legislation.pdf.

82. See id. $\ 304$ (stating in addition to creating the annual reports, the benefit officer would also have the powers and duties necessary to design the general or specific public benefit).

83. William H. Clark, Jr. \& Elizabeth K. Babson, How Benefit Corporations Are Redefining the Purpose of Business Corporations, 38 WM. MitCHELl L. REV. 817, 838 (2012).

84. See id. at 825-26 (recognizing many jurisdictions accept the idea that a corporation exists primarily to create wealth for its shareholders). 
advance its stated purposes, and in some cases exacerbates the problems it attempts to fix, one must first confront the debate regarding the proper role business entities should play in society. In this light, one must also consider what theories of corporate governance support the creation and structure of the benefit corporation.

\section{A. Of Shareholder Primacy and Shareholder Wealth Maximization}

The debate regarding the business corporation's proper role in society has long existed. The views of academics, executives, politicians, and society as a whole have ebbed and flowed throughout the last century and a half, largely dependent upon current economic conditions and the behavior of corporations at any given time. ${ }^{85}$ While the opinions and views of a business' role in society have changed, shareholder primacy and the maximization of shareholder wealth have long remained at the heart of corporate regulation in the United States. ${ }^{86}$ The reason for this consistency is largely practical. ${ }^{87}$ Although many have commented on the alleged inadequacies and potential negative societal results of corporate governance systems built on shareholder primacy, ${ }^{88}$ the fact remains that no better or more effective system of regulation currently exists. By understanding the simple yet elegant jurisprudential solution this doctrine provides to the difficult legal and practical issues surrounding the operation and regulation of corporate entities, one can understand why it has endured.

Although shareholders provide the capital for the formation and ongoing operation of corporations, the successful ongoing operation and management of a business requires the cooperation and input of numerous other individuals and institutions, such as employees, suppliers, managers,

85. See Anant K. Sundaram \& Andrew C. Inkpen, The Corporate Objective Revisited, 15 ORG. SCI. $350,351-52$ (2004) (discussing opposing views of corporate purpose and accountability reflected in numerous corporate governance debates in the United States throughout the previous 150 years).

86. See D. Gordon Smith, The Shareholder Primacy Norm, 23 J. CORP. L. 277, 296 (1998) (noting although courts did not develop the shareholder primacy norm until the 1830s, earlier business corporations and legal commentary "reflect a commitment to shareholder primacy" that predates these court cases).

87. See id. at 280 (describing the shareholder primacy norm as fundamental to corporate law).

88. See, e.g., Judd F. Sneirson, Green Is Good: Sustainability, Profitability, and a New Paradigm for Corporate Governance, 94 IOWA L. REV. 987, 1013-21 (arguing against shareholder wealth maximization and arguing for a "new paradigm" of corporate governance through voluntary charter amendments). 
and creditors. ${ }^{89}$ Conversely, the ongoing operation of a corporation affects these same individuals as well as outside factors such as the environment, the government, and society. ${ }^{90}$ The common term for these various constituents is "stakeholders." 91 Stakeholders' interests may sometimes align, but often they do not. In the management of any enterprise, some decisions will necessarily require tradeoffs between stakeholders' differing interests. ${ }^{92}$

A simple example will illustrate how this is the case. Suppose that due to increasing labor and raw material costs coupled with slowing demand, a particular textile plant operates at a loss for some time, and management has no reason to believe that this situation will change in the immediate or long-term future. Suppose further the company that owns the plant has other operations turning a profit, but not a sufficient profit to cover the losses of this particular plant. Also, assume this plant is the primary employer of the small town in which it is located, and it is likely the town will struggle to survive without the employment the plant provides.

Resolving this problem necessarily requires that the management of the company consider the stakeholders involved and decide whose interests should predominate. The decision will be heavily influenced by whomever the company's management owes a legal duty and exactly what that duty is. If management owes a duty only to act in the best interest of the shareholders, and if management believes the best decision for the shareholders and the long-term viability of the company is to close the plant, then management should take this course of action, despite the immediate harm it may cause to the community. If management owes a duty to act in the best interest of the employees of the plant, or perhaps to the community as a whole, then these stakeholders would likely assert that the company is required to keep the plant open. If management owes a duty to act in the best interest of all of these stakeholders, or in the interest of society as a whole, then management has an almost irreconcilable

89. See R. Edward Freeman \& David L. Reed, Stockbolders and Stakeholders: A New Perspective on Corporate Governance, 50 CAL. MGMT. REV. 88, 89-91 (1983) (discussing the development, adoption, and definition of the term stakeholder).

90. See id. at 90-91 (explaining the stakeholder concept evolved to address environmental, governmental, and societal issues).

91. See id. at 89 (including customers, employees, lenders, shareholders, and society in general as stakeholders).

92. See David Millon, Two Models of Corporate Social Responsibility, 46 WAKE FOREST L. REV. 523, 525 (2011) (highlighting the importance of this tradeoff in the constituency model of corporate social responsibility). 
conflict on its hands. Any decision management makes will injure one of the stakeholders, and if one of these stakeholder interests does not dominate over the others, then management has no real standard to follow. ${ }^{93}$

American jurisprudence has resolved this conflict in favor of shareholders. ${ }^{94}$ The obligations managers owe to shareholders are the duties of loyalty and care. ${ }^{95}$ The duty of care is often referred to in cases as the duty to further the best interests of the shareholders, ${ }^{96}$ but is also frequently couched in terms of shareholder wealth maximization. ${ }^{97}$ While courts and commentators frequently conflate shareholder primacy and shareholder wealth maximization into one concept, they are separable. ${ }^{98}$

93. See Anant K. Sundaram \& Andrew C. Inkpen, The Corporate Objective Revisited, 15 OrG. SCI. 350, 354-55 (2004) (detailing that organizations with multiple objectives who also attempt to manage multiple constituencies will likely create only confusion and unmet goals).

94. See, e.g., Unocal Corp. v. Mesa Petroleum Co., 493 A.2d 946, 955 (Del. 1985) (“[O]ur analysis begins with the basic principle that corporate directors have a fiduciary duty to act in the best interest of the corporation's stockholders.").

95. See id. ("As we have noted, their duty of care extends to protecting the corporation and its owners from perceived harm whether a threat originates from third parties or other shareholders."); see also PRINCIPLES OF CORP. GOVERNANCE \ 4.01 (1992) (explaining that a corporate director or officer has a duty to act with the care of a reasonably prudent person and to act with the best interests of the corporation in mind).

96. See David Millon, Two Models of Corporate Social Responsibility, 46 WAKE FOREST L. REV. 523, 527 (2011) (outlining Delaware courts have referred to this as a duty to "maximize the long-run interests of the corporation's stockholders" but have never articulated a duty to "maximize profits without regard to competing nonshareholder considerations").

97. See, e.g., eBay Domestic Holdings, Inc. v. Newmark, 16 A.3d 1, 34 (Del. Ch. 2010) ("Having chosen a for-profit corporate form, the Craigslist directors are bound by the fiduciary duties and standards that accompany that form. Those standards include acting to promote the value of the corporation for the benefit of its stockholders. The 'Inc.' after the company name has to mean at least that. Thus, I cannot accept as valid for the purposes of implementing the Rights Plan a corporate policy that specifically, clearly, and admittedly seeks not to maximize the economic value of a for-profit Delaware corporation for the benefit of its stockholders-no matter whether those stockholders are individuals of modest means or a corporate titan of online commerce.”).

98. See David A. Wishnick, Comment, Corporate Purposes in a Free Enterprise System: A Comment on eBay v. Newmark, 121 YALE L.J. 2405, 2412 (2012) (arguing shareholder wealth maximization should not be viewed as a mandatory approach to corporate purpose, but a default approach only if no other approach is set forth in the corporate charter; thus, shareholder primacy allows shareholders to contract, through the corporate charter, for a corporate purpose besides the maximization of shareholder wealth); see also Stephen M. Bainbridge, Director Primacy: The Means and Ends of Corporate Governance, 97 Nw. U. L. REV. 547, 574 (2003) ("Although often used interchangeably, the terms 'shareholder primacy' and 'shareholder wealth maximization' express distinct concepts.”); Jonathan R. Macey, A Close Read of an Excellent Commentary on Dodge v. Ford, 3 VA. L. \& BuS. REV. 177, 185 (2008) ("The goal of profit maximization for shareholders is the law, but it is only a default rule. If the shareholders and the other constituents of the corporate enterprise could agree on some other goal for the corporation, then the law clearly should not interfere."). 
However, because of the assumption that the shareholders' desire in investing in a company is to maximize their wealth, shareholder primacy and shareholder wealth maximization often correlate. ${ }^{99}$ It is largely due to the shareholder wealth maximization norm that shareholder primacy has been frequently criticized as requiring or incentivizing managers to act in dereliction of society and other stakeholders' interests in order to provide profit to shareholders. ${ }^{100}$

Though shareholder primacy is somewhat rigid in requiring managers of businesses owe fiduciary duties only to the shareholders of the corporation, the doctrine is remarkably flexible because of the judiciallycreated business judgment rule. ${ }^{101}$ The business judgment rule states that judges will not judicially invade decisions made by corporate managers as long as those decisions are in good faith and attributable to any rational business purpose. ${ }^{102}$ Thus, through the business judgment rule, managers have tremendous latitude in how they carry out corporate business affairs, including considering the interests of stakeholders and stockholders in making decisions. ${ }^{103}$

99. See Virginia Harper Ho, "Enlightened Shareholder Value": Corporate Governance Beyond the Shareholder-Stakeholder Divide, 36 J. CORP. L. 59, 104 (2010) ("That shareholder wealth maximization is an assumed term of the contract is generally justified on grounds that shareholders are relatively powerless to defend their own interests, that nonshareholders are adequately protected by law or contract, and finally, that the rule is the one most likely to maximize firm value and is therefore the rule that the contracting parties would have reached had they explicitly bargained for it.").

100. See, e.g., D. Gordon Smith, The Shareholder Primacy Norm, 23 J. CORP. L. 277, 281 (1998) (explaining those opposed to the shareholder primacy seek to address the needs of nonshareholders); see also Judd F. Sneirson, Green Is Good: Sustainability, Profitability, and a New Paradigm for Corporate Governance, 94 IOWA L. REV. 987, 1014 ("In fact, recent financial scholarship posits that the firm is not best served by a focus on shareholder wealth to the exclusion of all other considerations.").

101. See David Millon, Two Models of Corporate Social Responsibility, 46 WAKE FOREST L. REV. 523, 527 (2011) ("Under the business judgment rule, courts will not second-guess decisionsincluding decisions that appear to benefit nonshareholders at the expense of shareholders-as long as management can assert some plausible connection with the corporation's long-run best interests.")

102. See, e.g., eBay Domestic Holdings, 16 A.3d at 33 ("When director decisions are reviewed under the business judgment rule, this Court will not question rational judgments about how promoting non-stockholder interests - be it through making a charitable contribution, paying employees higher salaries and benefits, or more general norms like promoting a particular corporate culture-ultimately promote stockholder value.”); see also Sinclair Oil Corp. v. Levien, 280 A.2d 717, 720 (Del. 1971) (“A board of directors enjoys a presumption of sound business judgment, and its decisions will not be disturbed if they can be attributed to any rational business purpose.").

103. See eBay Domestic Holdings, 16 A.3d at 33 (reiterating corporate directors may promote nonshareholder interests through rational business decisions); see also Einer Elhauge, Sacrificing Corporate Profits in the Public Interest, 80 N.Y.U. L. REV. 733, 850 (2005) (declaring managers are not limited to making decisions based only on the shareholders' need to maximize their wealth). 
This latitude has led some scholars to note that because of the business judgment rule, shareholder wealth maximization is essentially an unenforceable legal standard when applied to the business activities of the modern business corporation. ${ }^{104}$ The shareholder primacy norm certainly places a theoretical limit on decisions of officers and directors, ${ }^{105}$ but as a practical matter, this limit is so easily overcome that it is difficult for a business decision to conflict with it. However, this seeming unenforceability is part of the appeal of shareholder primacy as a legal standard. A legal doctrine that restricts courts from substituting their judgment for that of private actors can provide great societal benefit simply by limiting judicial interference with corporate affairs. ${ }^{106}$ Thus, shareholder primacy as a legal standard, when coupled with the business judgment rule, is also important and useful for what it does not do; it does not create conflicting enforceable legal duties to multiple constituencies, and it restricts courts from meddling in the business affairs of private corporations. ${ }^{107}$

104. See, e.g., D. Gordon Smith, The Shareholder Primacy Norm, 23 J. CORP. L. 277, 285-86 (1998) ("If a director deviates from that standard by preferring the interests of a nonshareholder constituency to the interests of shareholders, the director technically violates the fiduciary duty of care. This would be only a 'technical' violation because, in duty of care cases, the universal application of the business judgment rule makes the shareholder primacy norm virtually unenforceable against public corporations' managers."); see also David Millon, Two Models of Corporate Social Responsibility, 46 WAKE FOREST L. REV. 523, 527 (2011) ("In any event, such pronouncements are of no practical importance, because shareholders lack the ability to challenge management policies that favor nonshareholder interests even if the result is reduction of profits.").

105. See eBay Domestic Holdings, 16 A.3d at 33 ("Under the Unocal standard, however, the directors must act within the range of reasonableness.").

106. See David A. Wishnick, Comment, Corporate Purposes in a Free Enterprise System: A Comment on eBay v. Newmark, 121 YALE L.J. 2405, 2412 (2012) ("One of the deep principles animating Delaware corporate law is a respect for private ordering."); see also Stephen M. Bainbridge, The Business Judgment Rule as Abstention Doctrine, 57 VAND. L. REV. 83, 128 (2004) ("If the business judgment rule is framed as an abstention doctrine, however, judicial review is more likely to be the exception rather than the rule. The court begins with a presumption against review. It then reviews the facts to determine not the quality of the decision, but rather whether the decision-making process was tainted by self-dealing and the like. The requisite questions to be asked are more objective and straightforward: Did the board commit fraud? Did the board commit an illegal act? Did the board self-deal? Whether or not the board exercised reasonable care is irrelevant, as well it should be. The business judgment rule thus builds a prophylactic barrier by which courts pre-commit to resisting the temptation to review the merits of the board's decision.").

107. While not the focus of this Article, courts do sometimes use a heightened standard of review in change of control or business sale situations. The perceived problems created by this heightened review are one of the primary reasons stated for the need of the benefit corporation form. See William H. Clark, Jr. \& Elizabeth K. Babson, How Benefit Corporations Are Redefining the Purpose of Business Corporations, 38 WM. MitChell L. REV. 817, 836 (2012) ("When defending takeover attempts, directors generally enjoy significantly less deference, as these decisions (including 
Numerous scholars have propounded theories for why shareholder primacy must, or should, be the standard for corporate governance. ${ }^{108}$ These philosophical and jurisprudential reasons aside, the existing corporate law system provides incredible flexibility to officers and directors and works remarkably well. ${ }^{109}$ While business corporations have at times been responsible for great harm in our society, society also enjoys an ever-rising standard of living in the United States derived at least in part from products and services corporations provide. ${ }^{110}$ The regulatory regime that allows for the creation of these benefits should not be cast aside lightly; however, the MBCL changes important aspects of existing corporate governance doctrine for a more unwieldy, and ultimately less useful, corporate form. ${ }^{111}$

\section{B. The Theoretical Underpinnings of the Benefit Corporation Structure and Corporate Purpose}

At the heart of the benefit corporation is the mandate that directors and officers consider the interests of the various stakeholders potentially affected by an entity's actions in carrying out its general public benefit

consideration of non-shareholder interests) on their face do not seem designed to maximize shareholder value."). However, even in change of control situations, directors of for-profit corporations have adequate means to protect their social mission, and in reality these fears have no substance. See Antony Page \& Robert A. Katz, Freezing Out Ben \& Jerry: Corporate Law and the Sale of a Social Enterprise Icon, 35 VT. L. REV. 211, 249 (2010) (noting the Ben \& Jerry's sale, pointed to by the drafters of the MBCL as an example for the need of a new corporate form to protect the social mission of for-profit companies, was not dictated by standard corporate law, and that " $[t]$ he law of publicly-traded corporations is sufficiently flexible to enable the creation of a double bottom line enterprise that is largely immune from takeover, thereby preserving control in the founders' missionfriendly hands.").

108. See Milton Friedman, The Social Responsibility of Business Is to Increase Its Profits, N.Y. TimeS MAG., Sept. 13, 1970, at 33 ("[T]he key point is that, in his capacity as a corporate executive, the manager is the agent of the individuals who own the corporation or establish the eleemosynary institution, and his primary responsibility is to them."); see also Allen Kaufman \& Ernie Englander, Behavioral Economics, Federalism, and the Triumph of Stakeholder Theory, 102 J. Bus. ETHICS 421, 428-32 (2011) (discussing the contract and trust theories for corporate governance and fiduciary duties to the corporation and its shareholders).

109. See Stephen M. Bainbridge, In Defense of the Shareholder Wealth Maximization Norm: A Reply to Professor Green, 50 WASH. \& LEE L. REV. 1423, 1446 (1993) ("For many years, the basic rule that shareholder interests come first has governed public corporations. That rule has helped produce an economy that is dominated by public corporations, which in turn has produced the highest standard of living of any society in the history of the world.").

110. See id. (touting the economic benefits of a corporate structure that places shareholder interests first while recognizing certain harms caused by corporate maneuvers).

111. See infra Part IV (discussing "practical implications of the benefit corporation's structure"). 
purpose. ${ }^{112}$ In a benefit corporation, while shareholders comprise one type of stakeholder whose interests must be considered, their interests do not have priority over those of any other stakeholder, nor do the interests of any particular stakeholder predominate over the interests of any others. ${ }^{113}$ Rather, in making decisions, managers of benefit corporations are required to consider the interests of all stakeholders in pursuit of the goal of seeking a "general public benefit" and any "specific public benefit" enumerated in the benefit corporation's articles of incorporation. ${ }^{114}$

Because of this public interest purpose, some have argued the preeminent duty of a benefit corporation is not a duty of care owed to any particular constituency, but what is essentially a duty of obedience to the general public benefit mission. ${ }^{115}$ Indeed, it is hard to read the MBCL and come to any other conclusion. ${ }^{116}$ However, even though it expressly

112. See William H. Clark, Jr. et al., Model Benefit Corporation Legislation, BENEFIT CORP. INFO. CTR. (Dec. 21, 2012), at \$S 301 \& 303, http://benefitcorp.net/storage/documents/Model_Benefit_ Corporation_Legislation.pdf (outlining the standard of conduct for officers and directors).

113. See id. (requiring directors and officers to consider equally the interests of all listed stakeholders). The MBCL does allow a benefit corporation to state in its articles "its intention to give priority to certain interests," but such a statement is not mandatory. Id. \$301(a)(3) (addressing priority of interests). Additionally, this priority must be "related to its accomplishment of its general public benefit purpose or of a specific public benefit purpose identified in its articles." Id.

114. Id. $\iint 301 \& 303$ (requiring officers and directors to consider all stakeholders' interests in making decisions).

115. See Briana Cummings, Note, Benefit Corporations: How to Enforce a Mandate to Promote the Public Interest, 112 COLUM. L. REV. 578, 590-92 (2012) (referring to this duty as "accountability to mission"); see also Christopher Lacovara, Note, Strange Creatures: A Hybrid Approach to Fiduciary Duty in Benefit Corporations, 2011 COLuM. Bus. L. REV. 815, 863-68 (arguing that given the structure of the benefit corporation statute, a duty of obedience to benefit purposes similar to that applied to nonprofits should be applied to benefit corporations).

116. See generally William H. Clark, Jr. et al., Model Benefit Corporation Legislation, BENEFIT CORP. INFO. CTR. (Dec. 21, 2012), at \$\$ 201 \& 301, http://benefitcorp.net/storage/documents/Model_ Benefit_Corporation_Legislation.pdf (conveying that priority in a benefit corporation is given to serving the general public benefit or any specific public benefit). At the very least, the duty of care owed to the corporation and to shareholders is defined exclusively in terms of the general public benefit and any specific public benefit enumerated, as the legislation states that the creation of such a benefit "is in the best interests of the benefit corporation." Id. \$201(c) (explaining the effect of the general and specific benefit purposes). However, a duty of care defines how something must be done, not what must be done. See Briana Cummings, Note, Benefit Corporations: How to Enforce a Mandate to Promote the Public Interest, 112 COLUM. L. REV. 578, 592 (2012) (describing differences in duties owed in benefit corporations). Thus, the duty to pursue and create a general public benefit is distinctly different from the standard duty of care. See id. (explaining how benefit corporation legislation expands upon statutory duties). 
disavows shareholder primacy ${ }^{117}$ and articulates this new public benefit corporate purpose, the MBCL retains much of the existing corporate structure by leaving ultimate accountability in the hands of the shareholders in the form of voting rights and the benefit enforcement proceeding. ${ }^{118}$ The MBCL's inconsistency in this regard makes it difficult to determine the exact corporate governance theory that explains and justifies the existence, organizational structure, and purpose of the benefit corporation.

\section{The Benefit Corporation As a Species of Stakeholder Theory}

One could argue the articulated purpose of the benefit corporation is most akin to the corporate purpose advocated by stakeholder theory, a strategic management theory that has long existed in academic literature. ${ }^{119}$ Stakeholder theory has developed in such a way that it defies neat definition, but it essentially espouses a shift of fiduciary duties and control from shareholders only to various constituencies (such as employees, creditors, customers, society in general, and shareholders as well), dubbed stakeholders, such that the corporation aims to maximize all stakeholders' interests, not just the interests of shareholders. ${ }^{120}$ Originally

117. William H. Clark, Jr. \& Elizabeth K. Babson, How Benefit Corporations Are Redefining the Purpose of Business Corporations, 38 WM. MitCHELL L. REV. 817, 838 (2012) (discussing the move away from shareholder primacy in benefit corporations).

118. See William H. Clark, Jr. et al., Model Benefit Corporation Legislation, BENEFIT CORP. INFO. CTR. (Dec. 21, 2012), at $\int \mathbb{S} 101$ (c) \& 305, http://benefitcorp.net/storage/documents/Model_ Benefit_Corporation_Legislation.pdf (maintaining shareholders' voting right, as provided in the state's business corporation law, and creating a right to bring a benefit enforcement proceeding).

119. See R. Edward Freeman \& David L. Reed, Stockholders and Stakeholders: A New Perspective on Corporate Governance, 50 CAL. MGMT. REV. 88, 89 (1983) ("[Stakeholder theory] says there are other groups to whom the corporation is responsible in addition to stockholders: those groups who have a stake in the actions of the corporation."). While numerous other scholars have contributed to stakeholder theory, R. Edward Freeman is one of the originators and leading minds in this area, and this Article will focus on stakeholder theory as envisioned by Freeman.

120. See James A. Stieb, Assessing Freeman's Stakeholder Theory, 87 J. Bus. ETHICs 401, 404 (2009) (defining stakeholder theory according to R. Edward Freeman). Stieb notes that "[m]any people seem to think they understand stakeholder theory when arguably they do not, though this may well be because the theory keeps shifting and re-manifesting." Id. He does, however, point out that the core of stakeholder theory has remained consistently a shift away from shareholder primacy towards the redistribution of benefits and decision-making power to stakeholders. Id. (addressing a shift in view from stockholder primacy to stakeholder primacy); see also Max B.E. Clarkson, A Stakeholder Framework for Analyzing and Evaluating Corporate Social Performance, 20 ACAD. MGMT. REV. 92, 112 (1995) ("The economic and social purpose of the corporation is to create and distribute increased wealth and value to all its primary stakeholder groups, without favoring one group at the expense of others."). 
propounded as a theory of strategic management, stakeholder theory has grown to encompass theories of the firm and corporate governance. ${ }^{121}$

The benefit corporation somewhat reorganizes the corporate purpose along stakeholder lines; however, it expressly disavows a fiduciary duty to any stakeholders besides the shareholders. ${ }^{122}$ Additionally, it expressly prohibits anyone except the benefit corporation itself, a shareholder, a director, an owner of $5 \%$ or more of any parent company of the benefit corporation, or a person expressly named in the bylaws or articles of the benefit corporation from bringing a benefit enforcement proceeding. ${ }^{123}$ Accordingly, although the MBCL requires the consideration of stakeholder interests, it deviates from Freeman's stakeholder theory view in that it does not provide these stakeholders with any type of decision-making power nor does it create an enforceable fiduciary duty owed to them. ${ }^{124}$ Thus, while the benefit corporation borrows conceptual elements of stakeholder theory, it is not a true stakeholder theory structure of corporate governance. $^{125}$

\section{The Benefit Corporation As a Species of the Contractarian Theory}

One could also argue that the benefit corporation follows a

121. See Eric W. Orts \& Alan Strudler, Putting a Stake in Stakeholder Theory, 88 J. Bus. ETHICS 606, 606-07 (2009) (contrasting a narrow and broad definition of stakeholder theory); see also Mario Minoja, Stakeholder Management Theory, Firm Strategy, and Ambidexterity, 109 J. Bus. ETHICS 67, 67 (2012) (noting that stakeholder theory has advanced to address not only issues of strategic management, but also societal and ethical issues).

122. See William H. Clark, Jr. et al., Model Benefit Corporation Legislation, BENEFIT CORP. INFO. CTR. (Dec. 21, 2012), at \301(d), http://benefitcorp.net/storage/documents/Model_ Benefit_ Corporation_Legislation.pdf ("A director does not have a duty to a person that is a beneficiary of the general public benefit purpose or a specific public benefit purpose of a benefit corporation arising from the status of the person as a beneficiary.").

123. See id. \305(b) (delineating which persons and entities have standing in benefit enforcement proceedings).

124. See James A. Stieb, Assessing Freeman's Stakeholder Theory, 87 J. Bus. ETHICs 401, 405 (2009) (asserting a redistribution of benefits to stakeholders, in the form of (1) a fiduciary relationship, and (2) decision-making power, define stakeholder theory).

125. Compare William H. Clark, Jr. et al., Model Benefit Corporation Legislation, BENEFIT CORP. INFO. CTR. (Dec. 21, 2012), at \$301(a), 301(d) \& 305(b), http://benefitcorp.net/storage/ documents/Model_Benefit_Corporation_Legislation.pdf (requiring benefit corporations to consider the interests of all stakeholders, yet not creating fiduciary duties and limiting standing to bring a benefit enforcement proceeding), with James A. Stieb, Assessing Freeman's Stakeholder Theory, 87 J. BuS. ETHICS 401, 405 (2009) (discussing fiduciary relationship benefits and decision-making power as two important component of Freeman's stakeholder theory). 
contractarian theory of the firm. ${ }^{126}$ The standard contractarian theory views the firm as a nexus of explicit and implicit contracts. ${ }^{127}$ The directors and officers act as the "contractual agents of the shareholders," and it is from this contractual relationship that fiduciary duties to the shareholders arise. ${ }^{128}$ While contractarian theory is typically associated with shareholder wealth maximization, ${ }^{129}$ the theory of shareholder wealth maximization as the ultimate goal for the firm is not its exclusive premise. For example, consider the statement from Frank H. Easterbrook and Daniel R. Fischel:

[W] hat is the goal of the corporation? Is it profit, and for whom? Social welfare more broadly defined? ... . Our response to such question is: who cares? If [The] New York Times is formed to publish a newspaper first and make a profit second, no one should be allowed to object. Those who came in at the beginning consented, and those who came later bought stock the price of which reflected the corporation's tempered commitment to a profit

126. See Stephen M. Bainbridge, Director Primacy: The Means and Ends of Corporate Governance, 97 Nw. U. L. REV. 547, 554 (2003) (depicting contractarian theory with the firm as the nexus of various interests such as shareholders, employees, managers, creditors, communities, and miscellaneous constituencies).

127. See id. ("Standard contractarian theory claims the corporation is a nexus of contracts.").

128. See id. at 548 ("Contractarian theory nevertheless continues to treat directors and officers as contractual agents of the shareholders, with fiduciary obligations to maximize shareholder wealth. Shareholders therefore retain a privileged position among the corporation's various constituencies, enjoying a contract with the firm granting shareholder ownership-like rights, such as the vote and the protection of fiduciary obligations by directors and officers.").

129. Contractarians assert that if the various stakeholders of a firm were to sit at a table and bargain with respect to the ultimate goal of the corporation, this bargain would result in shareholder wealth maximization as the goal of the firm. See id. at 577-84 (analyzing contractarian theory in terms of shareholder wealth maximization). The logic behind this view is based upon the fact that most non-shareholder constituents receive superior protection than shareholders from explicit contracts and regulatory legislation that protects their interests. Id. at 579 (addressing conflicts between shareholder and nonshareholder interests). Because shareholders have the least explicit contractual protection and thus are the most exposed to the risk of loss, they place a higher value on fiduciary duties than do other stakeholders, and thus are willing to offer more in this bargain to have the maximization of their interests be the basis of fiduciary duties. Id. ("Because shareholders will place a higher value on being the beneficiaries of director fiduciary duties than will nonshareholder constituencies, gains from trade are available, and a bargain would be struck in which shareholder wealth maximization is the chosen norm."). Contractarians typically also assert that shareholder wealth maximization leads to the most efficient allocation of corporate resources, which ultimately benefits all stakeholders in the long-run. Id. However, some corporate law scholars have questioned whether the result of this hypothetical bargain would be an agreed shareholder wealth maximization norm. See, e.g., Gregory Scott Crespi, Redefining the Fiduciary Duties of Corporate Directors in Accordance with the Team Production Model of Corporate Governance, 36 CREIGHTON L. REV. 623, 636 (2003) (arguing the result of such a hypothetical bargain would actually be an agreement imposing a fiduciary duty upon the board of directors to maximize the overall value of all of the stakeholders interests). 
objective. If a corporation is started with a promise to pay half of the profits to employees rather than the equity investors, that too is simply a term of the contract. ${ }^{130}$

Thus, while the standard contractarian theory asserts that shareholders and stakeholders would elect shareholder wealth maximization in a hypothetical bargain, it does not preclude shareholders from expressly agreeing to some other corporate purpose.

Because the benefit corporation is a voluntary corporate form that shareholders must adopt through the articles of incorporation, and is terminable by the shareholders, it is essentially contractarian in nature. ${ }^{131}$ Thus, the MBCL does not truly mark a departure from shareholder primacy, even though its drafters contend that it does. ${ }^{132}$ What the MBCL actually departs from is the norm of the maximization of shareholder wealth, a distinct concept separable from shareholder primacy. ${ }^{133}$ The method it uses to alter the norm of shareholder wealth maximization is through voluntary decision of the shareholders, who retain all voting rights; thus, the MBCL ultimately preserves shareholder primacy with respect to formation and control. ${ }^{134}$

While the MBCL gives shareholders some discretion in how they adopt

130. Frank H. EASTERbroOK \& Daniel R. Fischel, The ECONOMic Structure of CORPORATE LAW 35-36 (1991).

131. See William H. Clark, Jr. et al., Model Benefit Corporation Legislation, BENEFIT CORP. INFO. CTR. (Dec. 21, 2012), at $\int S$ 103-105, http://benefitcorp.net/storage/documents/Model_Benefit_ Corporation_Legislation.pdf (setting forth the requirements to incorporate and terminate a benefit corporation).

132. See William H. Clark, Jr. \& Elizabeth K. Babson, How Benefit Corporations Are Redefining the Purpose of Business Corporations, 38 WM. MiTCHELL L. REV. 817, 838 (2012) ("It is against the paradigm of shareholder primacy that benefit corporation statutes have been drafted.").

133. See David A. Wishnick, Comment, Corporate Purposes in a Free Enterprise System: A Comment on eBay v. Newmark, 121 YALE L.J. 2405, 2412-19 (2012) (arguing shareholder wealth maximization should not be viewed as a mandatory approach to corporate purpose, but a default only if no other approach is set forth in the corporate charter; thus, shareholder primacy allows shareholders to contract, through the corporate charter, for a corporate purpose besides the maximization of shareholder wealth); see also Stephen M. Bainbridge, Director Primacy: The Means and Ends of Corporate Governance, 97 NW. U. L. REV. 547, 574 (2003) ("Although often used interchangeably, the terms 'shareholder primacy' and 'shareholder wealth maximization' express distinct concepts."); Jonathan R. Macey, A Close Read of an Excellent Commentary on Dodge v. Ford, 3 VA. L. \& BUS. REV. 177, 185 (2008) ("The goal of profit maximization for shareholders is the law, but it is only a default rule. If the shareholder and the other constituents of the corporate enterprise could agree on some other goal for the corporation, then the law clearly should not interfere.").

134. See William H. Clark, Jr. et al., Model Benefit Corporation Legislation, BENEFIT CORP. INFO. CTR. (Dec. 21, 2012), at $\ 104$, http://benefitcorp.net/storage/documents/Model_Benefit_ Corporation_Legislation.pdf (addressing voting requirements to elect benefit corporation status). 
benefit corporation status, most of the MBCL becomes mandatory once elected. ${ }^{135}$ The MBCL is thus essentially contractarian with respect to corporate formation, yet limited in form because it requires adoption of a stakeholder theory of corporate purpose upon selection of the benefit corporation form. ${ }^{136}$ Thus, the benefit corporation's corporate form is ultimately an amalgam of contractarian shareholder primacy and stakeholder theory. The question for the effectiveness of such a structure is whether these mandated "contractual terms" the benefit corporation imposes are more beneficial to the goal of the social entrepreneur and to society in general rather than a traditional business corporate form where the shareholders and directors have more freedom to determine corporate purpose. Due to the very real practical problems with the benefit corporation's structure discussed in the next section, it is unlikely shareholders will voluntarily select the terms of the benefit corporation bargain because they can gain more benefit from constructing their own social mission terms under a traditional corporate form.

\section{THE Practical IMPLICATIONS OF THE BENEFIT CORPORATION'S STRUCTURE}

\section{A. Shareholders' Rights}

From the shareholder's perspective, election of the benefit corporation structure adds a degree of uncertainty and a potential loss of control over the organization as compared to a traditional business corporation. ${ }^{137}$

135. See id. $\$ 101 \mathrm{cmt}$. (“ $[\mathrm{A}]$ corporation that elects to be subject to this chapter will be subject to all of the provisions of the chapter and will not be able to vary their application to the corporation."). For example, the default stance of the MBCL is that no stakeholders' interests predominate over any others. See id. \301(a) (asserting that directors "need not give priority to the interests of a particular person or group"). The benefit corporation maintains the discretion to state in its articles that it intends to give priority to certain interests, but the priority must be "related to its accomplishment of its general public benefit purpose or a specific public benefit purpose identified in its articles," so this discretion is limited. Id. \$301(a)(3).

136. See Stephen M. Bainbridge, Director Primacy: The Means and Ends of Corporate Governance, 97 Nw. U. L. REV. 547, 584 (2003) ("One of the chief tenets of contractarianism is that the law ought to facilitate private ordering. The contractarian preference for default rules rather than mandatory rules in corporate law statutes follows from this proposition, as default rules provide the flexibility necessary for private ordering.").

137. See generally William H. Clark, Jr. et al., Model Benefit Corporation Legislation, BENEFIT CORP. INFO. CTR. (Dec. 21, 2012), at $\$ 301 \mathrm{cmt}$, http://benefitcorp.net/storage/documents/Model_ Benefit_Corporation_Legislation.pdf ("By requiring the consideration of interests of consitutencies other than the shareholders, the section rejects [case law] that directors must maximize the financial value of a corporation."). 
The shareholders essentially contract to require the benefit corporation to replace the goal of maximizing shareholder wealth with the goal of pursuing or creating a general public benefit. ${ }^{138}$ This obviously creates the potential for the loss of profit to the shareholder, as even the drafters of the MBCL acknowledge that pursuing a public interest will not always be the most profitable path for the firm. ${ }^{139}$ However, the shareholders may also lose some of their ability to control the direction of the entity and to hold officers and directors accountable to the organization's goals, including any social mission goals.

The benefit corporation provides principally two methods of enforcement of the benefit purpose. First, just like in a business corporation, shareholders maintain control through their voting power. ${ }^{140}$ The second method of enforcement is new: any shareholder can bring a benefit enforcement proceeding. ${ }^{141}$ The remedy which can be sought in a benefit enforcement proceeding is solely injunctive; the officers, directors, and the benefit corporation itself cannot be sued for monetary damages. ${ }^{142}$ For any given scenario, given the broad discretion afforded directors and officers of the benefit corporation, it is entirely possible that multiple shareholders could bring benefit enforcement proceedings advocating for conflicting positions which they perceive as being in the general public benefit. How would a judge decide such a case?

There are truly only two broad options: either the court will be willing to take an active role in evaluating corporate decisions and potentially substitute its own judgment for that of the corporation's managers or it

138. See id. \$201(a) (stating benefit corporations must create a general public benefit in addition to its purpose as a business corporation).

139. See William H. Clark, Jr. \& Elizabeth K. Babson, How Benefit Corporations Are Redefining the Purpose of Business Corporations, 38 WM. MitCHELl L. REV. 817, 835 (2012) ("While it is not true that all decisions that reflect consideration of non-shareholder interests lead to a reduction in shareholder value, and some in fact may lead to its increase, it is equally true that some might lead to reduced shareholder value, even over the long term.”).

140. See William H. Clark, Jr. et al., Model Benefit Corporation Legislation, BENEFIT CORP. INFO. CTR. (Dec. 21, 2012), at $\int 101(\mathrm{c})$, http://benefitcorp.net/storage/documents/Model_Benefit_ Corporation_Legislation.pdf (commenting that corporate attributes, such as shareholder voting rights, are not preempted by the MBCL if not expressly stated).

141. See id. $\$ 305$ (b) (providing a right of action for shareholders with at least $2 \%$ of shares).

142. See id. $\$ 305$ ("A benefit corporation shall not be liable for monetary damages under this [chapter] for any failure of the benefit corporation to pursue or create general public benefit or a specific public benefit.”); see also William H. Clark, Jr. \& Elizabeth K. Babson, How Benefit Corporations Are Redefining the Purpose of Business Corporations, 38 WM. MitCHELl L. REV. 817, 848-49 (2012) (referencing California's benefit corporation legislation, which "specifically excludes director, officer, and corporate liability for monetary damages"). 
will implement something akin to the business judgment rule for these organizations. The first option permits courts to micromanage difficult decisions at the request of shareholders. The second leaves shareholders with what is essentially no remedy because virtually any decision made by management, other than perhaps gross breaches of the duty of loyalty or illegal actions, can be justified based upon the broad considerations allowed in the MBCL's standards of conduct. The most likely outcome of this situation, as the drafters of the MBCL acknowledge, is that a court would apply a standard akin to the business judgment rule. ${ }^{143}$ However, such an outcome is far from certain.

If courts follow a standard similar to the business judgment rule, the result from the shareholders' perspective is that, in the daily management of the corporation, the shareholders and managers of a benefit corporation will be in no different legal condition than they would be in a standard corporation. ${ }^{144}$ However, at least in a standard business corporation, the business judgment rule has as its guiding star the requirement that the decision must bear some rational relationship to a benefit for the shareholders. ${ }^{145}$ Even though the business judgment rule almost inevitably leads to judges refusing to get involved in management decisions through legal proceedings, at least investors in traditional business corporations have a modicum of certainty that managers' ultimate loyalty lies with the shareholders. ${ }^{146}$

143. See William H. Clark, JR., ET AL., The Need and Rationale for the Benefit CORPoration: Why It Is the Legal Form THAT Best AdDresses the NeED of SOCIAL ENTREPRENEURS, INVESTORS, AND, UltimATELY, THE PuBliC 27 (2012), available at http://benefitcorp.net/for-attorneys/benefit-corp-white-paper ("If the corporation could show a meaningful good faith effort to pursue such positive impacts, then a judge would likely be reticent to interpose his or her judgment for the corporation's."). But see William H. Clark, Jr. \& Elizabeth K. Babson, How Benefit Corporations are Redefining the Purpose of Business Corporations, 38 WM. MITCHELL L. REV. 817, 832 (2012) (indicating the benefit enforcement proceeding is designed to provide "teeth" to enforce consideration of stakeholder interests, which would indicate a more strict review than that of the business judgment rule).

144. See David Millon, Two Models of Corporate Social Responsibility, 46 WAKE FOREST L. REV. 523, 527 (2011) (explaining that courts employing the business judgment rule concede to the decisions of management so long as they justify the decision as being in the best long-term interests of the corporation).

145. See Unocal Corp. v. Mesa Petroleum Co., 493 A.2d 946, 955 (Del. 1985) ("If a defensive measure is to come within the ambit of the business judgment rule, it must be reasonable in relation to the threat posed.").

146. See Sumantra Ghoshal, Bad Management Theories Are Destroying Good Management Practices, 4 ACAD. MGMT. LEARNING \& EDUC. 75, 81 (2005) (providing that the teaching of maximization of shareholder wealth dominates business schools such that it has "a level of legitimacy and certainty that few managers or academics now dare question"). 
Additionally, shareholders in a standard for-profit corporation have greater certainty that the business judgment rule will apply because there is an existing body of law already developed which enumerates their legal rights as shareholders. ${ }^{147}$ A shareholder in a benefit corporation has no such certainty. One can speculate that a court will apply a standard akin to the business judgment rule in benefit enforcement proceedings, but such a result is not certain. Faced with an entity with an express purpose of providing a general public benefit, a court could justifiably assume a much more expansive role in adjudicating disputes than the role it assumes for entities charged only with acting for the benefit of shareholders.

If courts elect to engage in a more active role with respect to these entities, the corporate governance structure of the benefit corporation suffers from the problem identified by Adolf Berle long ago-when a corporation is accountable to everyone, it is accountable to no one. ${ }^{148}$ Because no one stakeholder is the most important, there is no principled basis upon which to judge any particular decision. ${ }^{149}$ While the benefit corporation theoretically makes the company accountable to its mission as well as its stakeholders, in reality, no stakeholder could ever be sure how their rights would measure against those of the others and in whose interest any conflict would ultimately be resolved. This leaves the shareholder in a precarious position if an activist minority shareholder brings a benefit enforcement proceeding advocating the organization act in a manner that is detrimental to the other shareholders and the organization as a whole. ${ }^{150}$

If the current regulatory regime does not provide sufficient flexibility for social entrepreneurs, this level of uncertainty might be reasonably

147. See generally MODEL BUS. CORP. ACT \8.31 (2005) (outlining model rules regarding the business judgment rule; most states base their corporate laws on these rules).

148. See Adolf A. Berle, Jr., For Whom Corporate Managers Are Trustees: A Note, 45 HARV. L. REV. 1365, 1367-69 (1932) (detailing that unless some better system of accountability to stakeholders and the public is developed, removing management accountability to stockholders is to essentially give managers absolute control).

149. See James A. Stieb, Assessing Freeman's Stakeholder Theory, 87 J. Bus. ETHICs 401, 405 (2009) (writing stakeholder theory gives no basis for determining which stakeholders are the most important and should thus be given the most attention or decision-making authority).

150. William H. Clark, Jr. \& Elizabeth K. Babson, How Benefit Corporations Are Redefining the Purpose of Business Corporations, 38 WM. MitCheLL L. REV. 817, 832 (2012). Two of the primary drafters of the Model Benefit Corporation Legislation seem to advocate this, stating, "Mission-driven executives and investors are often in minority shareholder positions and would prefer that directors and officers be required to consider these expanded interests when making decisions, with a shareholder right of action providing the 'teeth' to enforce such consideration." Id. 
acceptable. However, given that current corporate law provides business entities with tremendous flexibility to pursue a social mission, this uncertainty is wholly unnecessary. ${ }^{151}$ In the best-case scenario, this body of law will mirror the business judgment rule, leaving shareholders of a benefit corporation in essentially the same position as if their entity had formed under standard corporate law. In the worst-case scenario, the benefit enforcement proceeding will be wielded by activist shareholders and courts to control the direction of the benefit corporation, weakening shareholders' ability to exert control through voting power. ${ }^{152}$

\section{B Stakeholders' Rights}

The benefit corporation structure provides no added benefit for nonshareholder stakeholders. By not providing stakeholders with any enforceable rights, the benefit corporation structure avoids the difficult and inefficient judicial problem that would develop if the benefit corporation were subject to suit by any of the stakeholders whose interests they are required to consider. ${ }^{153}$ However, in doing so, it falls short of

151. See infra Part V (analyzing the practical consequences created by the corporate structure of benefit corporations).

152. In a private company, the voting power of the shareholders can be significant; in a public company where ownership is more diffuse, the voting power is admittedly much less meaningful. See Margaret M. Blair \& Lynn A. Stout, A Team Production Theory of Corporate Law, 85 VA. L. REV. 247, 310 (1999) (noting that in a typical public firm, voting rights are held in such a diffuse manner that the right to vote is essentially meaningless, and that in reality directors control the organization). However, the MBCL weakens this control even further by potentially allocating some of it away from the majority shareholders towards the minority shareholders through the benefit enforcement proceeding, allowing them to wield it through legal process rather than their vote. See William H. Clark, Model Benefit Corporation Legislation, BENEFIT CORP. INFO. CTR. (Dec. 21, 2012), at $\ 102 \mathrm{cmt}$., http://benefitcorp.net/storage/documents/Model_Benefit_Corporation_Legislation.pdf (stating the definition of benefit enforcement proceeding "not only describes the action that may be brought under section 305, but also has the effect of excluding other actions against a benefit corporation and its directors and officers because [the MBCL] provides that 'no person may bring an action or assert a claim against a benefit corporation or its directors or officers' with respect to violation of the provisions of this chapter except in a benefit enforcement proceeding").

153. See Joseph Heath, Business Ethics Without Stakeholders, 16 BUS. ETHICS Q. 533, 543 (2006) ("If managers really are to be regarded as fiduciaries of stakeholder groups, it raises immediate difficulties with respect to questions of corporate governance. Freeman suggests that the managers must become like 'King Solomon,' adjudicating the rival claims ... as they see fit would create extraordinary agency risks. On the one hand, managers would need to be protected from being fired by shareholders upset over the performance of their investments. But even more significantly, it would become almost impossible for members of any stakeholder group to evaluate the performance of management."); see also Kenneth E. Goodpaster, Business Ethics and Stakeholder Analysis, 1 Bus. ETHICS Q. 53, 66 (1991) (" $[\mathrm{I}$ f we treat other stakeholders on the model of the fiduciary relationship between management and the stockholder, we will, in effect, make them into quasi-stockholders. We 
being a true stakeholder-centric model and leaves the benefit corporation with no effective accountability to the stakeholders for the mission it is to carry out on their behalf.

While the benefit corporation must state a general public benefit purpose ${ }^{154}$ this provides no real duty to stakeholders because they have no legal or voting recourse. The MBCL leaves the benefit corporation's sole enforcement mechanism and all decision-making authority to the shareholders, ${ }^{155}$ creating an entity whose structure is unlike the stakeholder theorists' ideal—an entity which provides for express fiduciary duties to stakeholders as well as some form of representation or decisionmaking ability with the organization. ${ }^{156}$ The shareholders of a benefit corporation could provide stakeholders with recourse either by giving or selling them shares or by voluntarily giving them standing to bring a benefit enforcement proceeding in the articles or bylaws. ${ }^{157}$ However, shareholders certainly are not incentivized to do so, and it is hard to imagine why they would as such an action would make the management of the entity much more difficult due to the potential for conflicting benefit

can do this, of course, if we choose to as a society. But we should be aware that it is a radical step indeed. For it blurs traditional goals in terms of entrepreneurial risk-taking, pushes decision-making towards paralysis because of the dilemmas posed by divided loyalties and, in the final analysis, represents nothing less than the conversion of the modern private corporation into a public institution and probably calls for a corresponding restructuring of corporate governance (e.g. representatives of each stakeholder group on the board of directors).").

154. William H. Clark, Jr. et al., Model Benefit Corporation Legislation, BENEFIT CORP. INFO. CTR. (Dec. 21, 2012), at $\$ 201$, http://benefitcorp.net/storage/documents/Model_Benefit_Corporation_ Legislation.pdf.

155. See Leo E. Strine, Jr., Our Continuing Struggle with the Idea That For-Profit Corporations Seek Profit, 47 WAKE FOREST L. REV. 135, 136 (2012) ("We act as if entities in which only capital has a vote will somehow be able to deny the stockholders their desires, when a choice has to be made between profit for those who control the board's reelection prospects and positive outcomes for the employees and communities who do not.").

156. See James A. Stieb, Assessing Freeman's Stakeholder Theory, 87 J. Bus. ETHICs 401, 404 (2009) (defining Freeman's stakeholder theory in terms of a rejection of stockholder primacy and a shifting of managerial fiduciary duties to stakeholders in general); see also Max B.E. Clarkson, A Stakeholder Framework for Analyzing and Evaluating Corporate Social Performance, 20 ACAD. MGMT. REV. 92, 112-13 (1995) ("But as managers make decisions and act in terms of stakeholder management in resolving inevitable conflicts of interest between stakeholder groups, they can no longer rely on 'the invisible hand' to solve problems and, instead, must deal directly themselves with ethics and moral principles.").

157. See William H. Clark, Jr. et al., Model Benefit Corporation Legislation, BENEFIT CORP. INFO. CTR. (Dec. 21, 2012), at $\int 305$, http://benefitcorp.net/storage/documents/Model_Benefit_ Corporation_Legislation.pdf (commenting on the necessary limitations imposed by most states upon judicial recourse). 
enforcement proceedings from multiple stakeholders. ${ }^{158}$

The drafters of the Model Benefit Corporation point to the third-party standard against which the annual benefit report must be judged as adding a level of accountability to stakeholders through transparency. ${ }^{159}$ However, this annual benefit report does not have to be audited, nor is there any adverse result associated with a negative report. ${ }^{160}$ The only measure of accountability this mechanism provides is to the shareholders who can vote to replace officers or directors based upon a negative report. ${ }^{161}$ This again provides no more accountability to stakeholders than they already have with a standard for-profit entity. Indeed, many large companies already provide public annual sustainability reports that stakeholders can access. ${ }^{162}$

\section{The Organization's Ability to Meet its Mission}

To continue to operate, organizations need an ongoing source of funds to finance their activities. For a business entity, these funds come from three sources: debt financing, equity financing, and revenue generated from ongoing operations. ${ }^{163}$ For many businesses, once initially capitalized, ongoing cash flows from operations are the main source of operational capital. ${ }^{164}$ A business must operate in a profitable manner to generate sufficient cash flows to fund its ongoing operations; in very simple terms, the revenue of the business must exceed its expenses. The realities of running a business dictate that a corporation that does not seek and generate profit will ultimately have less ability to aid society than one that does. ${ }^{165}$

158. William H. Clark, Jr. et al., The Need and Rationale for the Benefit Corporation: Why It Is the Legal Form That Best AdDresses the NeEds of Social Entrepreneurs, InVestors, AND, Ultimately, the Public 17-19 (2012), available at http://www.benefitcorp.net/for-attorneys/benefit-corp-white-paper.

159. Id. at 25 .

160. Id. at 10 .

161. Id. at $17-19$.

162. See Steve Lydenberg \& Graham Sinclair, Mainstream or Daydream? The Future for Responsible Investing, 33 J. CORP. CITIZENSHIP 47, 49 (2009) (pointing to the increase in use of CSR reports: "335 of the Financial Times Global 500 companies produced CSR reports").

163. Franklin Allen, Stewart C. Myers \& Richard A. Brealey, Principles of CORPORATE FINANCE 386 (9th ed. 2008).

164. $I d$.

165. See John Mackey, Rethinking the Social Responsibility of Business, REASON, Oct. 2005, at 10 available at http://reason.com/archives/2005/10/01/rethinking-the-social-responsi ("We want to improve the health and well-being of everyone on the planet through higher-quality foods and better nutrition, and we can't fulfill this mission unless we are highly profitable. High profits are necessary 
Although the benefit corporation does not abolish the profit motive, it does orient the organization around the vague and unquantifiable purpose of pursuing and creating a general public benefit rather than the primary goal of seeking profit. ${ }^{66}$ The pursuit and creation of a general public benefit is not sufficiently definite to serve as an obtainable goal. A corporation may seek to create a general public benefit as a part of the means by which a corporation may seek to fulfill a goal, but this pursuit is not definite enough to serve as an end in and of itself. This may seem like a distinction without a difference. It is not. How an organization frames its goals can have an effect on whether, and how efficiently, that goal is accomplished. ${ }^{167}$

Critics of the stakeholder theory, which articulates a goal similar to that of the benefit corporation, state:

To the extent that stakeholder theory argues that firms should pay attention to all their constituencies, the theory is unassailable. Taken this far, stakeholder theory is completely consistent with value maximization, which implies that managers must pay attention to all constituencies that can affect the firm.

But there is more to stakeholder theory than this. Any theory of action must tell the actors, in this case the managers and boards of directors, how to choose among multiple competing and inconsistent constituent interests. Customers want low prices, high quality, expensive service, etc. Employees want high wages, high quality working conditions, and fringe benefits including vacations, medical benefits, pensions, and the rest. Suppliers of capital want low risk and high returns. Communities want high charitable contributions, social expenditures by firms to benefit the community at large, stable employment, increased investment, and so on. And so it goes with every conceivable constituency. Obviously any decision criterion-and the objective function is at the core of any decision criterion-must specify how to make the tradeoffs between these often conflicting and inconsistent demands. ${ }^{168}$

to fuel our growth across the United States and the world. Just as people cannot live without eating, so a business cannot live without profits.").

166. William H. Clark, Jr. et al., Model Benefit Corporation Legislation, BENEFIT CORP. INFO. CTR. (Dec. 21, 2012), at $\ 201$, http://benefitcorp.net/storage/documents/Model_Benefit_Corporation_ Legislation.pdf.

167. See Eric W. Orts \& Alan Strudler, Putting a Stake in Stakeholder Theory, 88 J. Bus. ETHICS 605, 609 (2009) ("Ample social science research supports the common sense idea that if one conceives of one's goals in vague terms, one achieves less.").

168. Michael C. Jensen, Value Maximization, Stakeholder Theory, and the Corporate Objective Function, 12 Bus. ETHICS Q. 235, 241 (2002). 
Balancing the needs of stakeholders necessarily requires an objective function that the organization seeks to maximize and against which various stakeholders' needs are balanced. ${ }^{169}$ For such a function to be effective, it must have as its end a quantifiable value maximization goal of some kind. ${ }^{170}$ The independent third-party standards that serve as the basis for the MBCL's definition of "general public benefit" do not provide business leaders with a measurable final objective. ${ }^{171}$ This is largely because any type of broad social mission defies easy quantification. ${ }^{172}$ Nevertheless, because the MBCL requires benefit corporations to dedicate themselves to this vague and unquantifiable general public benefit goal, and opens them up to suits for injunctive relief if a shareholder feels they are not reaching this goal, the MBCL actually hampers these organizations from accomplishing the societal missions they intend to fulfill.

The MBCL specifically allows benefit corporations to pursue a "specific public benefit," but this goal does not replace the general public benefit purpose; it only supplements it. ${ }^{173}$ The legislative drafters specifically state the general public benefit standard is useful because socially

169. See id. at 238-41 (noting an organization needs a single-valued objective function to maximize to make reasoned decisions and to reach the most socially efficient outcome for the firm and its constituents).

170. See id. at 238 ("Without a definition of the meaning of better there is no principled foundation or choice.").

171. See, e.g., INTERNATIONAl ORganization FOR STANDARDiZATION, DisCOVERING ISO 26000, at 3-4 (2010), available at http://www.iso.org/iso/discovering_iso_26000.pdf. The ISO 26000 standard is one of the third-party standards referenced by B Lab for benefit corporations to use. It provides descriptions of how a company can implement social responsibility standards into its business practices. Id. at 3. However, it articulates as its goal " $[\mathrm{w}]$ hen approaching and [practicing] social responsibility, the overarching goal for an organization is to maximize its contribution to sustainable development." Id. at 8 . Such a statement is so vague as to be virtually meaningless. See Global Reporting Initiative, Sustainability Reporting Guidelines v.3.1, at 2 (2011), available at https://www.globalreporting.org/reporting/latest-guidelines/Pages/default.aspx (stating as its thirdparty standard: "The goal of sustainable development is to 'meet the needs of the present without compromising the ability of future generations to meet their own needs."'). While the GRI Reporting Guidelines may aid an organization in determining and reporting the societal and environmental impact of their operations, they provide little to no guidance about how to reach this sustainable development goal or even how to measure it. Id. at 3.

172. See Briana Cummings, Note, Benefit Corporations: How to Enforce a Mandate to Promote the Public Interest, 112 Colum. L. REV. 578, 602-13 (2012) (noting the problems with the accountability metrics proposed by the MBCL for social missions).

173. See William H. Clark, Jr. \& Elizabeth K. Babson, How Benefit Corporations Are Redefining the Purpose of Business Corporations, 38 WM. MiTCHELL L. REV. 817, 841 (2012) ("A company may also designate a specific public benefit, in addition to its general public benefit purpose. This ensures that a benefit corporation can pursue any specific mission, but that the company as a whole is also working toward general public benefit.”). 
responsible investors are not interested in companies that "trade-off" on values or stakeholder interests. ${ }^{174}$ This naive statement ignores the reality that trade-offs are absolutely necessary: one cannot please everyone all of the time. ${ }^{175}$ Although the benefit corporation could certainly have an internal business strategy that articulates a more specific, quantifiable corporate goal, the standard of judgment in any benefit enforcement proceeding is the broad general public benefit standard of the statute. Thus, the benefit corporation ultimately provides less flexibility in determining the organization's mission than standard corporate law, placing it at a competitive disadvantage against business corporations that have a quantifiable value maximization goal but also provide societal benefits. ${ }^{176}$

\section{Officer and Director Accountability}

Because of the uncertain dimensions of the benefit enforcement proceeding, shareholders have less certainty of purpose and potentially less control in the benefit corporation than they do under the standard corporate form. The stakeholders have only aspirational statements of

174. See William H. Clark, Jr. ET al., The Need and Rationale for the Benefit

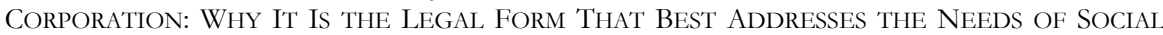
ENTREPRENEURS, InVESTORS, AND, UltimATELY, THE PuBliC 21 (2012), available at http://www.benefitcorp.net/for-attorneys/benefit-corp-white-paper ("The entrepreneurs, investors, consumers and policy makers interested in new corporate form legislation are not interested in, for example, reducing waste while increasing carbon emissions, or reducing both while remaining indifferent to the creation of economic opportunity for low-income individuals or underserved communities.").

175. See Eric W. Orts \& Alan Strudler, Putting a Stake in Stakeholder Theory, 88 J. Bus. ETHICS 606, 611 (2009) ("However, it would be wrong to contend that stakeholder interests can be always made to align. Some stakeholder theorists sing the praises of finding solutions to conflicts that improve the position of all parties, but no serious proponent of stakeholder theory argues that the relevant interests can always be made to align. What, then, does stakeholder theory advise a manager or other business decision maker to do when stakeholder interests intractably conflict? Nothing: except to say that a manager must 'balance' the interest of all the stakeholders. We contend that this unhelpful advice.").

176. See Anant K. Sundaram \& Andrew C. Inkpen, The Corporate Objective Revisited, 15 ORG. SCI. 350, 353-54 (2004) (noting that maximizing shareholder value is the most efficient method to maximize value for all stakeholders of a firm); see also Michael C. Jensen, Value Maximization, Stakeholder Theory, and the Corporate Objective Function, 12 Bus. ETHICS Q. 235, 237 (2002) ("What is commonly known as stakeholder theory, while not totally without content, is fundamentally flawed because it violates the proposition that any organization must have a single-valued objective as a precursor to purposeful or rational behavior. In particular, I argue that a firm that adopts stakeholder theory will be handicapped in the competition for survival because, as a basis for action, stakeholder theory politicizes the corporation, and it leaves its managers empowered to exercise their own preferences in spending the firm's resources.”). 
purpose, an unenforceable duty to consider their interests in pursuing a general public benefit, and the cold comfort of transparency without consequence. Indeed, the benefit corporation seems tailor-made to benefit one party - the social entrepreneurs who wish to make it as difficult as possible to have their particular social mission disrupted, regardless of the desires of shareholders who provide them with capital. ${ }^{177}$

One of the articulated needs for this new business form suggests "the current legal framework is structured to ensure profit maximization, not social responsibility. Because of this, entrepreneurs with a mission-driven business may be reluctant to accept outside capital from investors who may not share their long-term vision for social and environmental responsibility." 178 Essentially, the drafters of the MBCL see this reluctance as a negative, preferring to design a system where social entrepreneurs are comfortable accepting capital from investors who may not share their social mission. As a legal and moral proposition, there is no valid reason why social entrepreneurs should be afforded such a privileged status or that society should offer them any protection or incentive to accept capital from investors who do not agree with the overarching purpose for which the capital will be deployed. ${ }^{179}$ Ultimately,

177. See, e.g., eBay Domestic Holdings, Inc. v. Newmark, 16 A.3d 1, 32 (Del. Ch. 2010) (acknowledging that two majority shareholders established a plan to bind future stockholders from deviating from their public-service mission, culture, and business model). eBay Domestic Holdings, Inc. v. Newmark is one of the cases most commonly cited in justifying the need for a new, socially-oriented corporate form. The court in that case noted that the founders of Craigslist were expressly using defensive devices to attempt to keep the social mission of Craigslist intact after their death. Id. The court disapproved of this tactic, noting, "[Two majority shareholders] ask this Court to validate their attempt to use a pill to shape the future of the space-time continuum." Id.

178. William H. Clark, Jr. \& Elizabeth K. Babson, How Benefit Corporations Are Redefining the Purpose of Business Corporations, 38 WM. MitCHELL L. REV. 817, 824 (2012) (footnote omitted).

179. See Leo E. Strine, Jr., Our Continuing Struggle with the Idea That For-Profit Corporations Seek Profit, 47 WAKE FOREST L. REV. 135, 149-50 (2012) ("If, they said, you remain incorporated in Delaware, your stockholders will be able to hold you accountable for putting their interests first. You must go elsewhere, to a fictional land where you can take other people's money, use it as you wish, and ignore the best interests of those with only a right to vote. In this fictional land, I suppose a fictional accountability mechanism will exist whereby the fiduciaries, if they are a controlling interest, will be held accountable for responsibly balancing all these interests. Of course, a very distinguished mind of the political left, Adolph Berle, believed that when corporate fiduciaries were allowed to consider all interests without legally binding constraints, they were freed from accountability to any. Equally unrealistic is the idea that corporations authorized to consider other interests will be able to do so at the expense of stockholder profits if voting control of the corporation remains in the stock market. Just how long will hedge funds and mutual funds subordinate their desire for returns to the desire of a founder to do good?’”). 
this statement strikes at one of the key aspects of the benefit corporation-the weakening of management accountability to any stakeholder. ${ }^{180}$

Management of the benefit corporation is still ultimately accountable to the shareholders through the voting mechanism. ${ }^{181}$ However, because it is virtually impossible to determine whether a goal as vague as creating a general public benefit is being met, it is difficult for shareholders of a benefit corporation to evaluate director performance and determine how to vote. ${ }^{182}$ Additionally, if the benefit corporation is held diffusely, then this voting power may be essentially meaningless. ${ }^{183}$ While this is also the case in existing diffusely-held public business corporations, this problem is exacerbated by the presence of the benefit enforcement proceeding. Depending on the scope of judicial involvement courts undertake through the benefit enforcement proceeding, the benefit corporation may potentially dilute the accountability of directors to their shareholders. ${ }^{184}$ For example, if the shareholders vote to remove a director they feel is

180. See Adolf A. Berle, Jr., For Whom Corporate Managers Are Trustees: A Note, 45 HARV. L. REV. 1365, 1368 (1932) ("Nothing is accomplished, either as a matter of law or of economics, merely by saying that the claim of this group [stockholders] ought not to be 'emphasized.' Either you have a system based upon individual ownership or property or you do not. If not-and there are at the moment plenty of reasons why capitalism does not seem ideal-it becomes necessary to present a system (none has been presented) of law or government, or both, by which responsibility for control of national wealth and income is so apportioned and enforced that the community as a whole, or at least the great bulk of it, is properly taken care of. Otherwise the economic power now mobilized and massed under the corporate form, in the hands of a few thousand directors, and the few hundred individuals holding 'control' is simply handed over, weakly, to the present administrators with a pious wish that something nice will come out of it all.").

181. See William H. Clark, Jr. et al., Model Benefit Corporation Legislation, BENEFIT CORP. INFO. CTR. (Dec. 21, 2012), at $\ 101(\mathrm{c})$, http://benefitcorp.net/storage/documents/Model_Benefit_ Corporation_ Legislation.pdf (stating that corporate attributes, such as shareholder voting rights, are not preempted by the MBCL if not expressly stated).

182. See Joseph Heath, Business Ethics Without Stakeholders, 16 BUS. ETHICS Q. 533, 543 (2006) ("But even more significantly, it would become almost impossible for members of any stakeholder group to evaluate the performance of management. It is difficult enough for shareholders to determine whether managers are actually maximizing profits, given available resources. But when profits can be traded off against myriad other objectives as they see fit, then there is really no alternative but to trust the word of managers when they say that they are doing the best they can.").

183. See Margaret M. Blair \& Lynn A. Stout, A Team Production Theory of Corporate Law, 85 VA. L. REV. 247, 310 (1999) (noting that in a typical public firm, voting rights are held in such a diffuse manner that the right to vote is essentially meaningless, and that in reality directors control the organization).

184. See supra Part IV.A (acknowledging that, in theory, the benefit corporation makes the company accountable to its shareholders, while, in reality, its shareholders are left uncertain about their rights relative to others). 
spending too much money on the social mission, an activist minority shareholder could file a benefit enforcement proceeding seeking reinstatement of the director because he was faithfully fulfilling his duties by pursuing a general public benefit. ${ }^{185}$

The drafters of the MBCL seem to be perfectly fine with this shift in power, stating that " $[\mathrm{m}]$ ission-driven executives and investors are often in minority shareholder positions and would prefer that directors and officers be required to consider these expanded interests when making decisions, with a shareholder right of action providing the 'teeth' to enforce such consideration." 186 As an initial matter, the factual premise for this statement seems suspect. One of the primary purposes for the benefit corporation is to spur social entrepreneurship. ${ }^{187}$ Presumably, these social entrepreneurs are in a majority ownership position when they start companies. However, assuming the factual premise for this statement is correct and social entrepreneurs must typically sell a majority position to outside investors, it strikes at the heart of traditional notions of democratic fairness that a founder who remains a minority holder could permissibly control the direction of the company through legal process. ${ }^{188}$ While the legal process of the benefit enforcement proceeding appears on its face to provide the ability to hold officers and directors accountable to the benefit corporation's mission, it applies it in a haphazard and unprincipled manner not reasonably tailored to be an effective accountability mechanism.

\section{E. Investors' Willingness to Provide Capital}

The drafters of the MBCL assert that because the legal status of a benefit corporation will assure investors the company is pursuing a social

185. See id. (discussing the scope of review of benefit enforcement proceeding). Given the potential power that could be granted to any individual shareholder through such a proceeding, the uncertainty surrounding its scope should loom large in the mind of shareholders and investors.

186. William H. Clark, Jr. \& Elizabeth K. Babson, How Benefit Corporations Are Redefining the Purpose of Business Corporations, 38 WM. MitChELL L. REV. 817, 832 (2012). Given that shareholders still have voting rights in the benefit corporation, it is hard to see how the "mission-driven executives and investors" that are in the minority can use the benefit enforcement proceeding to further their cause unless the drafters of the MBCL envision courts taking a very active role in these cases. Id.

187. Id. at $823-24$.

188. Frank H. Easterbrook \& Daniel R. Fischel, The Economic Structure of CORPORATE LAW 35-36 (1991). Even assuming the contractarian view of corporate purpose espoused by Easterbrook \& Fischel, this view assumes that the contract rights purchased by the shareholders will be honored. These rights include the right to vote on certain issues and control the direction of the corporation to the extent allowed by these voting rights. Thus, even a secondary share purchaser who purchased shares with the knowledge of the company's social mission should not have his or her voting power diluted via a cause of action. 
mission, they will have easier access to socially-responsible investments (SRI) than standard corporations. ${ }^{189}$ However, even advocates of SRI acknowledge that while these investors care about the social mission of the companies in which they invest, they still invest with the goal of making a profit. ${ }^{190}$ Additionally, most SRIs come from institutional investors, where professional money managers make investment decisions. ${ }^{191}$ These investors are fully entrenched in the business and cultural norm commonly taught in business schools - that the purpose of the corporation is to maximize shareholder wealth. ${ }^{192}$

When these investors face the opportunity to invest in a benefit corporation that articulates its primary purpose as the creation of a general public benefit or, on the other hand, a socially minded business corporation that embraces a profit goal via a socially responsible business plan, the latter is more likely to receive capital. ${ }^{193}$ While the legal reality may be that the maximization of shareholder wealth is largely unenforceable in a traditional corporation, the cultural norm that the shareholder maximization expectation carries in business is powerful. ${ }^{194}$ Perception can become reality, and it is likely to do so in this case. The added credibility of social responsibility resulting from a benefit corporation designation is unlikely to overcome this effect because of the

189. See William H. Clark, Jr. \& Elizabeth K. Babson, How Benefit Corporations Are Redefining the Purpose of Business Corporations, 38 WM. MiTCHELL L. REV. 817, 822-23 (2012) (discussing the rapid growth of the SRI movement and its influence over corporations to pursue social missions or other activist forms).

190. See, e.g., Meir Statman, Quite Conversations: The Expressive Nature of Socially Responsible Investors, J. Fin. PlanNing, Feb. 2008, at 44 ("Socially responsible investors care about their investment returns. They generally believe that they can expect returns no lower than other investors.").

191. See Sustainable and Responsible Investing Top Ten Frequently Asked Questions and Answers, US SIFF. FOR SUSTAINABLE AND RESPONSIBLE INV. 1, 3 (2011), available at http://ussif.org/resources/factsheets_resources/documents/10mediaquestions2011_final.pdf

("With $\$ 2.3$ trillion in assets involved in one or more SRI categories, institutional investors dominate the SRI universe.").

192. See generally Sumantra Ghoshal, Bad Management Theories Are Destroying Good Management Practices, 4 ACAD. MGMT. LEARning \& EDUC. 75, 75 (2005) (teaching business students that the goal of American corporations is to maximize shareholder value).

193. See, e.g., Victoria Vyvyan, Chew Ng \& Mark Brimble, Socially Responsible Investing: The Green Attitudes and Grey Choices of Australian Investors, 15 CORP. GOVERNANCE: INT'L REV. 370, 379-80 (2007) (finding that even among investors who indicated strong attitudes toward socially responsible causes such as environmentalism, financial performance was the most influential factor in their investing decisions).

194. See Sumantra Ghoshal, Bad Management Theories Are Destroying Good Management Practices, 4 ACAD. MGMT. LEARNING \& EDUC. 75 (2005) ("Many of the worst excesses of recent management practices have their roots in a set of ideas that have emerged from business school academics over the last [thirty] years."). 
increasing amounts of information investors can access to verify the social responsibility of a company. ${ }^{195}$ While the drafters of the MBCL state that the CSR reports are inadequate for investors due to fears of "greenwashing,"196 the MBCL does not remedy this issue. A benefit corporation can manipulate a CSR report just as easily as a business corporation. The benefit enforcement proceeding provides very little additional legal recourse to an investor who has invested in a benefit corporation based upon a misleading or inaccurate annual benefit report as the only remedy is injunctive. ${ }^{197}$

The benefit corporation status simply adds no additional benefit for investors or for social entrepreneurs seeking investment capital. While a benefit corporation certainly has the ability to pursue a profit motive by placing more emphasis on the public benefit requirement and expressly derogating the profit motive to this public benefit, the benefit corporation merely adds uncertainty for investors hoping to realize profit. All else being equal, when investors perceive uncertainty, fundamentals of finance dictate they will either reject an investment altogether or require a higher rate of return on invested capital. ${ }^{198}$ Thus, the MBCL will likely have the opposite of its intended effect and will be less likely to attract socially responsible investors than a social mission-oriented company acting under a traditional business corporate form with which investors are familiar.

195. See Steve Lydenberg \& Graham Sinclair, Mainstream or Daydream? The Future for Responsible Investing, 33 J. CORP. CITIZENSHIP 47, 49 (2009) (recognizing the increased transparency in companies and noting 335 of the 500 companies in the Financial Times Global 500 produce CSR reports).

196. William H. Clark, Jr. et al., The Need and Rationale for the Benefit Corporation: Why It Is the Legal Form THAT Best AdDresses the NeEds of Social ENTREPRENEURS, InVESTORS, AND, Ultimately, THE Public 2-4 (2012), available at http://www.benefitcorp.net/storage/documents/Benecit_Corporation_White_Paper_1_18_2013.pd

197. See William H. Clark, Jr. et al., Model Benefit Corporation Legislation, BENEFIT CORP. INFO. CTR. (Dec. 21, 2012), at $\ 305(\mathrm{a})$, http://benefitcorp.net/storage/documents/Model_Benefit_ Corporation_Legislation.pdf (indicating that if a shareholder were to attempt to sue for monetary damages for fraud or some other common law cause of action, their rights would be the same whether they were an investor in a benefit corporation or a standard business corporation).

198. Cf. Richard A. Brealey et AL., Principles of Corporate FinANCE 214 (9th ed. 2008) ("Shareholders are happy for companies to plow back this money into the firm, so long as it goes to positive-NPV investments.”). 


\section{A BetTer WAY: Ethical Managers RunNing Traditional BUSINESS CORPORATIONS}

The MBCL actually runs the risk of unintentionally setting the CSR movement back by creating a false dichotomy between benefit corporations and business corporations. The development of entities like the benefit corporation creates the perception in the minds of entrepreneurs that they cannot carry out a social mission through a traditional business corporation. A new entity status may also create the perception in the minds of consumers, investors, and society as a whole that they should not expect much from typical corporations or should excuse their poor behavior as legally required under the shareholder wealth maximization norm - when it is in fact not-and that only these specially designated entities can or should be expected to pursue any social goals. The level of wealth and influence accumulated by business corporations far exceeds that which benefit corporations can expect to accumulate given the practical constraints discussed above. ${ }^{199}$ These business corporations can, do, and should create benefits for society while seeking a profit, even if their objective is to maximize shareholder wealth. Thus, society will receive much greater benefit by focusing attention on how to further monitor and incentivize the CSR efforts of traditional business rather than creating an unneeded new corporate form.

\section{A. Business Corporations Can Maintain a Social Mission Under Current Corporate Law}

Despite the concerns of the drafters of the MBCL, the norm of shareholder wealth maximization is largely unenforceable, and does not prevent business corporations from pursuing a social mission. ${ }^{200}$ In

199. Compare BenEFIT CORP. White PAPER, at 3 (pointing out the estimated size of the SRI market in the United States is $\$ 2.3$ trillion, approximately $10 \%$ of U.S. assets under management (citing US SIF: The Forum for Sustainable and Responsible Investment, 2010 Report on Socially Responsible Investing (2010), available at http://ussif.org/)), with Market Capitalization of Listed Companies, WORLD BANK, http://data.worldbank.org/indicator/CM.MKT.LCAP.CD (last visited Apr. 7, 2013) (listing America's total average market capitalization of publicly listed companies as \$15.6 trillion in 2011). While there is certainly some overlap between these two numbers, as some SRI money is invested in public companies, this comparison provides a rough example of the vast disparity in size and impact.

200. See Lynn A. Stout, Why We Should Stop Teaching Dodge v. Ford, 3 VA. L. \& Bus. REv. 163, 176 (arguing that Dodge v. Ford is no longer good law, has not been largely adopted by other courts, and should no longer be taught in law schools to support the assertion that shareholder wealth maximization is the sole purpose of a corporation); see also Steinway v. Steinway \& Sons, 40 N.Y.S. 718,720 (1896) ("As industrial conditions change, business methods must change with them, and 
practice, many corporations consider the social implications in their decision-making, and the overreaction to concerns about maximizing shareholder wealth is unwarranted. ${ }^{201}$ In fact, managers of corporations have never been legally obligated to maximize profits, and no state statutorily requires corporate profit maximization or makes profit maximization the sole objective of corporations. ${ }^{202}$

Consequently, many traditional corporations, including Starbucks, Safeway, Cisco, Google, GE, Wal-Mart, and Alcoa engage in substantial charitable and social missions. ${ }^{203}$ Safeway, for instance, sets aside a percentage of its income for charity while continuing to retain its profit maximization purpose. ${ }^{204}$ EBay donated $\$ 1$ million worth of pre-initial public offering stock to the Community Foundation Silicon Valley. ${ }^{205}$ About a year after eBay went public, the foundation realized $\$ 40$ million by selling the stock, increasing its resources for non-profit projects. ${ }^{206}$ Google, Inc. maintains a philanthropic arm called "Google.org."207 Google.org claims to have provided more than $\$ 100$ million in grants and more than $\$ 1$ billion of in-kind technological support to charitable causes

acts become permissible which at an earlier period would not have been considered to be within corporate power.").

201. See, e.g., Janet E. Kerr, Sustainability Meets Profitability: The Convenient Truth of How the Business Judgment Rule Protects a Board's Decision to Engage in Social Entrepreneurship, 29 CARDOZO L. REV. 623, 624-29 (2007) (discussing various companies, such as eBay, Google, Dow Chemical, and GlaxoSmithKline, with strong social missions).

202. See Einer Elhauge, Sacrificing Corporate Profits in the Public Interest, 80 N.Y.U. L. REV. 733, 738 (2005) (arguing that corporate managers historically consider the public interest at the expense of profits).

203. See Leslie Berliant, B Corporation, a New W ay of Doing Business?, INSIDEClimATE News (July 13, 2009), http://insideclimatenews.org/news/20090713/b-corporation-new-way-doing-business? page $=2$ (noting that many companies are moving toward sustainability by altering their bylaws because of changing customer needs); see also Companies That in 2010 Gave Charities More Than 5\% of Their 2009 Profits, CHRON. OF PHILANTHROPY (July 24, 2011), available at http://philanthropy.com/ article/Chart-Companies-That-in-2010/128358/; Douglas McGray, Networking Philantbropy; The Men Bebind eBay Are Leading a High-Tech Revolution That Is Turning Charitable Giving on Its Head, L.A. TIMES, Jan. 21, 2007, at I14, available at http://articles.latimes.com/2007/jan/21/magazine/tmphilanthropy03 (calling eBay's founders leaders of the high-tech charitable revolution).

204. Companies That in 2010 Gave Charities More Than 5\% of Their 2009 Profits, CHrON. OF PHILANTHROPY (July 24, 2011), http://philanthropy.com/article/Chart-Companies-That-in-2010/ $128385 /$

205. Douglas McGray, Network. Philanthropy: The Men Bebind eBay Are Leading a High-Tech Revolution That Is Turning Charitable Giving on Its Head, L.A. TIMES, Jan. 21, 2007, at I14, available at http://articles.latimes.com/2007/jan/21/magazine/tm-philanthropy03.

206. Id.

207. GoOGLE.ORG, http://www.google.org (last visited Apr. 7, 2013). 
in 2012 alone. ${ }^{208}$

One could argue that the above examples are companies that engage in social issues as side projects somewhat related to their business, but that their social mission is not a core purpose or objective of their business. However, a prime example of a profit-driven public company with a strong social mission at the very core of its business is Whole Foods Market, Inc. (Whole Foods). ${ }^{209}$ Whole Foods is a standard, for-profit corporation in Texas. ${ }^{210}$ It is a large publicly-traded company committed to earning a profit for its investors. ${ }^{211}$ However, Whole Foods also articulates various social core values that it adheres to and seeks to further. $^{212}$ In addition to fulfilling these core values through operations, Whole Foods gives a minimum of $5 \%$ of its profits every year to communities and non-profit organizations. ${ }^{213}$ Independent parties verify that these values are not merely rhetoric and that Whole Foods actually follows them in how it conducts business. ${ }^{214}$

Whole Foods succinctly expresses its commitment to its various stakeholders in a portion of its "Declaration of Interdependence":

Satisfying all of our stakeholders and achieving our standards is our goal. One of the most important responsibilities of Whole Foods Market's leadership is to make sure the interests, desires and needs of our various stakeholders are kept in balance. We recognize that this is a dynamic

208. Explore How We Gave This Year, GOOGLE GIVING, http://www.google.com/giving/ (last visited Apr. 7, 2013).

209. Declaration of Interdependence, WHOLE FOODS MARKET, http://wholefoodsmarket.com/ mission-values/core-values/declaration-interdependence (last visited Apr. 7, 2013).

210. Whole Foods Market, Inc., Annual Report (Form 10-K) (Sept. 30, 2012).

211. See Declaration of Interdependence, WHOLE FOODS MARKET, http://wholefoodsmarket.com/ mission-values/core-values/declaration-interdependence (last visited Apr. 7, 2013) ("We are the stewards of our shareholder's investments ... [and] are committed to increasing long term shareholder value.").

212. See id. (listing the core values of Whole Foods Market as "selling the highest quality natural and organic products available," "satisfying and delighting our customers," "supporting team member excellence and happiness," "creating wealth through profits and growth," "caring about our communities [and] our environment," "creating ongoing win-win partnerships with our suppliers," and "promoting the health of our stakeholders through healthy eating education").

213. Declaration of Interdependence, WHOLE FOODS MARKET, http://wholefoodsmarket.com/ mission-values/core-values/declaration-interdependence (last visited Apr. 7, 2013).

214. See Whole Foods Market Named to “World's Most Ethical Companies” List, PR NEWswIRE (Mar. 16, 2012), http://www.prnewswire.com/news-releases/whole-foods-market-named-to-worlds-mostethical-companies-list-142949045.html (recognizing Whole Foods Market on Ethisphere Institute's World's Most Ethical Companies); see also Partner Profile Whole Foods Market, EPA (Jan. 15, 2013), http://www.epa.gov/greenpower/partners/partners/wholefoodsmarket.htm (recognizing Whole Foods Market with Green Power Awards in 2004, 2005, 2006, 2007, 2010, and 2012). 
process. It requires participation and communication by all of our stakeholders. It requires listening compassionately, thinking carefully and acting with integrity. Any conflicts must be mediated and win-win solutions found. Creating and nurturing this community of stakeholders is critical to the long-term success of our company. ${ }^{215}$

John Mackey, the CEO of Whole Foods, has described himself as a "free market libertarian" with no hostility to profits. ${ }^{216}$ However, he believes that through being more stakeholder-centric rather than shareholder-centric, Whole Foods tremendously increases shareholder value while also benefitting customers, employees, vendors, communities, and the environment. ${ }^{217}$ While Mackey's statements about corporate purpose do not mirror those found in case law, ${ }^{218}$ Whole Foods has managed to accomplish its mission within the existing framework of corporate law. 219

As the drafters of the MBCL acknowledge, there is an increasing number of independent certifications available to help consumers and investors verify the social responsibility claims of these companies. ${ }^{220}$ Indeed, the transparency mechanisms of the MBCL are built upon the availability of third-party standards for evaluating a company's social mission. $^{221}$ These third-party standards are equally as available to business corporations as they are to benefit corporations. Moreover, because of consumer and investor demand, more companies are moving

215. Declaration of Interdependence, WHOLE FOODS MARKET, http://wholefoodsmarket.com/ mission-values / core-values/declaration-interdependence (last visited Apr. 7, 2013).

216. John Mackey, Retbinking the Social Responsibility of Business, REASON, at 2 (Oct. 1, 2005, 12:00 AM), http://reason.com/archives/2005/10/01/rethinking-the-social-responsi/print.

217. Id.

218. See id. at 9 ("In contrast to Friedman, I do not believe maximizing profits for the investors is the only acceptable justification for all corporate actions. The investors are not the only people who matter. Corporations can exist for purposes other than simply maximizing profits."). Of Whole Foods' philanthropic programs, he states: "That said, I believe such programs would be completely justifiable even if they produced no profits and no P.R. This is because I believe the entrepreneurs, not the current investors in a company's stock, have the right and responsibility to define the purpose of the company." Id. at 3.

219. See Whole Foods Market, Inc., Annual Report (For 10-K) (Sept. 30, 2012) (listing Whole Foods Market as a world leader in organic food sales that has traded on the NASDAQ since 1992).

220. See William H. Clark, Jr. Et Al., White Paper, The Need and Rationale for THE Benefit Corporation: Why It Is the LEgAL Form that BeST ADDRESSES THE NeEDS of Social ENTrepreneurs, InVestors, AND, Ultimately, the Public 3 (2012); see, e.g., 2012 World's Most Ethical Companies, ETHISPHERE, http://ethisphere.com/wme/ (last visited Apr. 7, 2013) (publishing an annual list of the world's most ethical companies, broken down by industry).

221. See BENEFIT CORP. White PAPER, at 18-19 (listing transparency requirements for annual benefit reports). 
towards publishing annual CSR reports to provide these constituencies with the information they need to evaluate companies' social efforts. ${ }^{222}$

Society is better benefited by encouraging more companies to operate like those with strong CSR efforts than it is by creating new hybrid entities. If social entrepreneurs feel constrained within the current legal framework, the appropriate reaction is to better educate entrepreneurs about the flexibility they have within this framework to operate as a socially-minded company. Creating new corporate forms and other "hybrid" entities only serves to perpetuate the myth that business corporations do not have the flexibility to pursue social missions or benefit stakeholders besides shareholders.

\section{B. Available Corporate Law Mechanisms to Protect a Social Mission}

To the extent social entrepreneurs are concerned about protecting the social missions of their respective organizations, there are legal precautions they can take under existing corporate law. ${ }^{223}$ Using these mechanisms in a traditional business corporation provides social entrepreneurs with more flexibility in determining corporate purpose than the benefit corporation structure. $^{224}$

1. Articles of Incorporation, Bylaws, or Shareholder Agreements Can State the Company's Social Mission

The articles of incorporation govern the management of the corporation. ${ }^{25}$ Placing a social mission in a corporation's articles of incorporation or bylaws to alert possible shareholders of the specific obligation the corporation has undertaken to society is permissible and would not offend corporate laws. ${ }^{226}$ Indeed, the B-Lab "B-Corp"

222. See Steve Lydenberg \& Graham Sinclair, Mainstream or Daydream?: The Future for Responsible Investing, 33 J. CORP. CITIZENSHIP 47 (2009) (noting the increase in the number of corporations issuing CSR reports and considering social responsibility in business).

223. See generally DEL. CODE ANN. tit. 8, \102(b)(1) (2010) (allowing any provisions, including social missions, to be listed in a certificate of incorporation or company bylaws).

224. See supra Part II.B. The benefit corporation structure requires the corporate purpose of creating a general public benefit, which provides less flexibility for organizations that may wish just to pursue a particular social mission that their abilities and financial situation are more suited to pursue.

225. See generally DEL. CODE ANN. tit. 8, \102(a)(3) (2010) (requiring only a general statement that a corporation will engage in lawful activity).

226. See, e.g., id. $\$ 102(\mathrm{a})(3) \&$ (b)(1). Delaware, regarded as the most shareholder friendly state, expressly sets forth that the only statement of purpose required in a corporation's articles of incorporation is a general statement that the corporation's purpose is to "engage in any lawful act or activity for which corporations may be organized." Id. \$102(a)(3). Additionally, corporations may 
certification presupposes the ability to make such changes to corporate documents. ${ }^{227}$ While there is little to no decisional law regarding how a corporation with a non-shareholder maximizing purpose in its articles would be treated in a shareholder derivative suit, it seems clear that in such a case the shareholders would not succeed in alleging any wrongdoing when directors are only acting in accordance with the shareholders' wishes as articulated in the articles of incorporation. ${ }^{228}$ Given the wide latitude in the management of corporate affairs already afforded to directors and officers under the business judgment rule, ${ }^{229}$ it is hard to imagine that shareholders could ever challenge the pursuit of a social mission with the added protection afforded by a statement of that mission in the articles of incorporation. ${ }^{230}$

specifically state:

Any provision for the management of the business and for the conduct of the affairs of the corporation, and any provision creating, defining, limiting and regulating the powers of the corporation, the directors, and the stockholders, or any class of the stockholders, or the governing body, members, or any class or group of members of a nonstock corporation; if such provisions are not contrary to the laws of this State.

Id. $\$ 102(\mathrm{~b})(1)$. Socially minded entrepreneurs may also place their companies' social mission in the corporate bylaws and the effect would be essentially the same as placing it in the articles of incorporation. However, because most corporate statutes permit directors to modify the bylaws (as opposed to modification of articles of incorporations which must be approved by both directors and shareholders), the social mission could be more easily dropped if only in the bylaws. See Rakhi I. Patel, Facilitating Stakeholder-Interest Maximization: Accommodating Beneficial Corporations in the Model Business Corporation Act, 23 ST. THOMAS L. REV. 135, 146 (2010) ("[G]iven that bylaws need not be of public record and directors can easily amend them, stakeholders may not always be aware as to when their interests are not being maximized.").

227. See B LAB, http://www.bcorporation.net/become-a-b-corp/how-to-become-a-b-corp/ 120 (last visited Apr. 7, 2013) (providing forms for B Corp declaration while indicating that the key is to announce the philanthropic component of your business).

228. See Jonathan R. Macey, A Close Read of an Excellent Commentary on Dodge v. Ford, 3 VA. L. \& BUS. REV. 177, 185 (2008) ("The goal of profit maximization for shareholders is the law, but it is only a default rule. If the shareholders and other constituents of the corporate enterprise could agree on some other goal for the corporation, then the law clearly should not interfere.").

229. See supra Part III.A.

230. This analysis is no different in change-in-control situations. While not the focus of this Article, change-in-control situations are commonly set forth as the biggest concern in the minds of social entrepreneurs due to a heightened standard of review in such situations. See William H. Clark, Jr. \& Elizabeth K. Babson, How Benefit Corporations Are Redefining the Purpose of Business Corporations, 38 WM. MitCHELL L. REV. 817, 836-38 (2012) (emphasizing director responsibilities during the sale of a philanthropic for-profit corporation). However, numerous anti-takeover devices are available such that these concerns are unfounded. See Antony Page \& Robert A. Katz, Freezing Out Ben \& Jerry: Corporate Law and the Sale of a Social Enterprise Icon, 35 VT. L. REV. 211, 249 (2010) (professing that current corporate law is sufficient to protect philanthropic intentions of for-profit companies). Additionally, under any corporate form, the most effective means of preventing such situations is 
Shareholders are also free to contract among themselves and with the corporation to ensure the corporation pursues its social mission. ${ }^{231}$ Shareholder agreements may also restrict alienability of ownership to prevent investors who do not share the founding entrepreneurs' social mission from acquiring control of the corporation and directing the entity away from its social goal. ${ }^{232}$ Shareholder agreements regarding ownership transfers vary in terms, but they generally include provisions dealing with rights of first refusal and inalienability of shares. ${ }^{233}$ These agreements are binding on company owners based on traditional contract doctrines and can be useful for corporate founders who intend to pursue social missions. ${ }^{234}$

\section{Founders Can Maintain Control Through Capital Structure}

Entrepreneurs who seek to benefit from the rise in the collective social conscience are not exempt from the need to raise money to fund their operations. Yet, many traditional sources of capital often do not have

maintaining control of the company through the capital structure, since a sale or merger requires the cooperation of the shareholders. See id. at 231 (noting the two principle ways to buy a company are through a tender offer or a merger, both of which require the shareholders to participate, either through agreeing to sell or through approving the merger). This structure is not changed by the MBCL, as it retains traditional voting rights with respect to these types of transactions other than it requires the "minimum status vote" of a two-thirds majority, which many states already require for traditional business corporations. See William H. Clark, Jr. et al., Model Benefit Corporation Legislation, BENEFIT CORP. INFO. CTR. (Dec. 21, 2012), at $\int 104(b) \&$ cmt., http://benefitcorp.net/storage/ documents/Model_Benefit_Corporation_Legislation.pdf ("Subsection (b) applies when a corporation is becoming a benefit corporation indirectly in the context of a fundamental transaction.... [T] he change to benefit corporation status must be approved by at least the minimum status vote."). Even this super-majority requirement would not prevent an outside group from purchasing control of the company through the ability to control who sits on the board of directors. Additionally, traditional corporate law already allows for a virtually limitless array of voting arrangements useful for maintaining control. See generally MODEL BUS. CORP. ACT \ 7.20-.29 (2005) (outlining the methods and procedures for corporate voting).

231. See Einer Elhauge, Sacrificing Corporate Profits in the Public Interest, 80 N.Y.U. L. REV. 733, 737 (2005) (stating shareholders can contract to protect their legal rights).

232. See Maurer v. Haines City Mobile Park \& Sales, Inc., No. WD-00-051, 2002 WL 479771, at *4 (Ohio Ct. App. Mar. 29, 2002) ("[T]he most likely purpose for share transfer restrictions in close corporations is to prevent outsiders from purchasing shares and potentially damaging the company.").

233. See Stephen J. Leacock, Share Transfer Restrictions in Close Corporations As Mechanisms for Intelligible Corporate Outcomes, 3 FAULKNER L. REV. 109, 152-55 (2011) (detailing methods of restricting transfer of shares in shareholder agreements, such as right-of-first-refusal clauses and testamentary disposition clauses).

234. See id. at 112 (extolling the importance of including clear restrictive language in the transfer restriction and declaring contract law to be the enforcement mechanism for such language). 
interests aligned with those of social entrepreneurs. The MBCL does not truly address this problem. For example, in both benefit and traditional corporations, the entity's social mission can be usurped if uninterested investors purchase a controlling percentage of shares. ${ }^{235}$

The case of eBay Domestic Holdings, Inc. v. Newmark ${ }^{236}$ is instructive on this point. ${ }^{237}$ This case involved eBay's purchase of shares in online classified ads company Craigslist, Inc., which is organized as a Delaware for-profit corporation but is more dedicated to its social mission and culture than making a profit. ${ }^{238}$ One of Craigslist's three shareholders, Jim Knowlton, sold his $28.4 \%$ share of the company to eBay in a deal in which the majority shareholders, Craig Newmark (the founder) and Jim Buckmaster (CEO and President), each received $\$ 8$ million. $^{239}$ Throughout the sale process, eBay made Buckmaster and Newmark aware of its intent to monetize the website and that it would be interested in acquiring a larger stake in the company. ${ }^{240}$ Newmark and Buckmaster claimed to be more interested in what they perceived as Craigslist's social mission and had no desire to further monetize the company's classified ad offerings. $^{241}$ This difference in views eventually led to conflict and created a situation where Buckmaster and Newmark, who still held majority ownership, initiated defensive measures intended to prevent the

235. See William H. Clark, Jr. et al., Model Benefit Corporation Legislation, BENEFIT CORP. INFO. CTR. (Dec. 21, 2012), at \$101, http://benefitcorp.net/storage/documents/Model_Benefit_ Corporation_Legislation.pdf (asserting that the MBCL applies general corporate law, including shareholder voting rights, to the benefit corporation except as otherwise set forth in the legislation). While the benefit enforcement proceeding might provide the minority shareholders with potential injunctive relief to enforce the benefit purpose in such a situation, this is not at all certain. See supra Part IV.D. Additionally, if non-mission minded shareholders obtain a super-majority of shares, they can simply terminate the benefit corporation status. There is simply no statutory substitute for maintaining control.

236. eBay Domestic Holdings, Inc. v. Newmark, 16 A.3d 1 (Del. Ch. 2010).

237. See id. at 33 " "Time did not hold that corporate culture, standing alone, is worthy of protection as an end in itself.").

238. See id. at 8 (noting of Craigslist: "Though a for-profit concern, [C]raigslist largely operates its business as a community service. Nearly all classified advertisements are placed on [C]raigslist free of charge. Moreover, $[\mathrm{C}]$ raigslist does not sell advertising space or otherwise market its services, $[\mathrm{C}]$ raigslist's revenue stream consists solely of fees for online job postings in certain cities and apartment listings in New York City").

239. Id. at 11 .

240. Id. at 10.

241. See id. (breaking off negotiations until eBay agreed to stop pushing for a greater equity share). 
loss of this social mission of the company. ${ }^{242}$ The court struck down two of these defensive measures - the shareholder rights plan and the right of first refusal agreement/dilutive issuance — as a breach of fiduciary duty. ${ }^{243}$

This case is mostly associated with its shareholder wealth maximization language used in striking down the defensive measures. ${ }^{244}$ However, there are more important practical lessons gleaned from it. Because Buckmaster and Newmark still had majority control through their shares, the loss of their defensive measures in this case did not mean the loss of their social mission or control of the company. ${ }^{245}$ Thus, Buckmaster and Newmark were wise in maintaining their control, which virtually eliminated any impact eBay could have on Craigslist's social mission.

But if Buckmaster and Newmark had been more judicious in their decision to accept eBay as their third shareholder, they could have saved themselves the time, money, and headache. EBay made its intent abundantly clear throughout the negotiation process; it originally expressed a desire to purchase all of Craigslist and also expressly retained a right to compete with Craigslist in the shareholder agreement it entered into. ${ }^{246}$ EBay's clear intent was to gain a larger foothold in the online classified ads space, and it saw Craigslist as a mechanism to do so. ${ }^{247}$ From the facts of

242. Id. at 22-25. Specifically, Buckmaster and Newmark amended Craigslist's charter and bylaws to implement a staggered board, which cut off eBay's ability to appoint a board member, implemented a "poison pill" shareholder rights plan aimed at preventing eBay from waging a takeover attempt, and executed a right of first refusal agreement/dilutive issuance agreement aimed at giving Craigslist a perpetual right of first refusal on all shares, further restricting the ability of the company to change ownership.

243. Id. at 48.

244. The threat that Buckmaster and Newmark identified in implementing the shareholder rights plan was a threat to the corporate culture and social mission of Craigslist, particularly with respect to the loss of this social mission after their death. $I d$. at 32. The court rebuffed this as a valid basis for a poison pill, stating:

Jim and Craig opted to form [C]raigslist, Inc. as a for-profit Delaware corporation and voluntarily accepted millions of dollars from eBay as part of a transaction whereby eBay became a stockholder .... Those standards include acting to promote the value of the corporation for the benefit of its stockholders .... Thus, I cannot accept as valid for the purposes of implementing the Rights Plan a corporate policy that specifically, clearly, and admittedly seeks not to maximize the economic value of a for-profit Delaware corporation for the benefit of its stockholders-no matter whether those stockholders are individuals of modest means.

Id. at 34 .

245. See id. at 40-41 (allowing Jim and Craig to maintain control of the board through a shareholders agreement)

246. Id. at 11-12.

247. See id. at 14 (describing the series of steps taken by eBay to establish itself in the internet classifieds market). 
the case, it appeared that while Buckmaster and Newmark expressed that the social mission was more important to them than profit, the windfall they would receive from the eBay stock purchase was also quite tantalizing. ${ }^{248}$

The decision to sell the shares ultimately resided with Knowlton. ${ }^{249}$ However, as majority shareholders Newmark and Buckmaster had significant bargaining power, as evidenced by a stock purchase agreement they were able to negotiate with eBay that had certain restrictions in it. ${ }^{250}$ Had Newmark and Buckmaster used their negotiating power more wisely, they very possibly could have found a purchaser for Knowlton's shares whose interests were more in line with their own. Perhaps this would have resulted in Newmark and Buckmaster not each individually receiving $\$ 8$ million; if they were truly not interested in monetizing Craigslist, then lining their own pockets through the sale of someone else's stock should not have been an important factor in their decision.

As this case illustrates, there is no substitute for maintaining control of one's company and exercising judgment in seeking capital. Studies show that socially conscious businesses which have successfully maintained their respective social missions have accomplished this by initially seeking funds from like-minded investors. ${ }^{251}$ Several companies, including Shorebank Corp., Google Inc., Levi Strauss \& Co., The New York Times Co., and The Timberland Co., succeeded in their respective social missions by following this principle. ${ }^{252}$ Shorebank Corporation, a Chicago-based bank that obtained its initial capital from socially committed sources including church groups and individuals, raised additional capital by issuing new investors a different class of stock with no aspect of

248. See id. at 10 ("At an early stage of the negotiations, Jim and Craig learned that Knowlton was to receive $\$ 15$ million for his shares. Upon receiving this revelation, Craig explained in an email to $[\mathrm{C}]$ raigslist's outside counsel that he was 'definitely not interested in seeing the dumb guy [Knowlton] get that figure.' As negotiations progressed, eBay came to believe that Jim and Craig wanted to be paid whatever Knowlton was paid before they would agree to the eBay investment.").

249. See id. at 9 (detailing Knowlton's ultimate path to selling his shares in Craigslist to eBay).

250. Contained in the stock purchase agreement were the following: confidentiality provisions, eBay's right to consent to certain transactions, stock transfer restrictions on shares held by Buckmaster, Newmark, \& eBay, eBay's right to compete with Craigslist, and the consequences that would occur if eBay exercised this right. $I d$. at 11-12.

251. See J. Gregory Dees \& Beth Battle Anderson, For-Profit Social Ventures, 2 Soc. ENTREPRENEURSHIP 1, 17-19 (2003) (offering examples of successful for-profit companies with philanthropic tendencies that included values statements in their prospectus when seeking investors such as Levi Strauss and Timberland).

252. See id. at 18 (acknowledging that family-controlled companies have the best chance of retaining control). 
control. ${ }^{253}$ Google Inc.'s founders are also able to pursue their social mission by maintaining control of the company through a special class of stock. $^{254}$ The founders hold the superior class of stock with significant voting power while other investors are permitted to purchase the other class. $^{255}$ This capital structure provides the founders with substantial security to pursue their social mission and commitment to for-profit philanthropy. ${ }^{256}$

\section{CONCLUSION}

Corporations, like individuals, can create great societal benefit. They can also do terrible things. The direction a corporation takes depends heavily on its managers; corporate law is not to blame for their malfeasance. Shareholder primacy and shareholder wealth maximization are merely convenient scapegoats upon which to place the blame for wrongful conduct. The reality is that corporations can maximize shareholder wealth while still considering the interests of all stakeholders; by pursuing a wealth maximization goal in a socially responsible manner, all stakeholders can be benefited. ${ }^{257}$ Moreover, the traditional business corporation's structure does not require shareholder wealth maximization as the primary goal of the corporation, and thus provides social entrepreneurs with ample flexibility to pursue a social mission. ${ }^{258}$

While the intent of the MBCL is laudable, there are inherent problems with its corporate governance structure that make it unwieldy and ineffective. The benefit corporation fails as a useful legal structure because it sets forth a general public benefit purpose, but provides the parties most affected by this purpose with no corresponding effective method for enforcing it. Additionally, this general public benefit purpose is vague, unquantifiable, and does not serve as an adequate objective for purposeful corporate action. ${ }^{259}$ By requiring managers to pursue multiple objectives

253. Id

254. Dana Brakman Reiser, Charity Law's Essentials, 86 NOTRE DAME L. REV. 1, 46-47 (2011).

255. Id.

256. Id. at 47.

257. See generally Michael C. Jensen, Value Maximization, Stakeholder Theory, and the Corporate Objective Function, 12 BUS. ETHICS Q. 235, 253 (2002) (asserting that mission and value creation for shareholders can coexist); see also Anant K. Sundaram \& Andrew C. Inkpen, The Corporate Objective Revisited, 15 ORG. SCI. 350, 353-54 (2004) (concluding that maximizing shareholder wealth may synergistically maximize stakeholder wealth relative to other management focuses).

258. See supra Part V.

259. See generally Michael C. Jensen, Value Maximization, Stakeholder Theory, and the Corporate Objective Function, 12 BUS. ETHICS Q. 235, 247 (2002) (stating that multiple performance measures 
and consider all stakeholders' interests equally, the benefit corporation makes it more likely that none of these objectives will be fulfilled. ${ }^{260}$ Because of these problems, it is unlikely that the benefit corporation will be successful in its goal of furthering social entrepreneurship.

muddle managers' ability to make effective decisions); see also Anant K. Sundaram \& Andrew C. Inkpen, The Corporate Objective Revisited, 15 ORG. SCI. 350, 353 (2004) ("Having more than one objective function will make governing difficult, if not impossible.”).

260. See Joseph Heath, Business Ethics Without Stakeholders, 16 Bus. ETHICS Q. 533, 543 (2006) ("The history of state-owned enterprises shows that the 'multiple objectives' problem can completely undermine managerial discipline, and lead to firms behaving in a less socially responsible manner than those that are explicitly committed to maximizing shareholder value."). 